\title{
Plasma density gradients at the edge of polar ionospheric holes: the absence of phase scintillation
}

\author{
Luke A. Jenner ${ }^{1}$, Alan G. Wood ${ }^{1}$, Gareth D. Dorrian ${ }^{1}$, Kjellmar Oksavik ${ }^{2,3}$, Timothy K. Yeoman ${ }^{4}$, \\ Alexandra R. Fogg ${ }^{4}$, and Anthea J. Coster ${ }^{5}$ \\ ${ }^{1}$ School of Science \& Technology, Nottingham Trent University, Nottingham, UK \\ ${ }^{2}$ Birkeland Centre for Space Science, Department of Physics and Technology, University of Bergen, Bergen, Norway \\ ${ }^{3}$ Arctic Geophysics, University Centre in Svalbard, Longyearbyen, Norway \\ ${ }^{4}$ Department of Physics and Astronomy, University of Leicester, Leicester, UK \\ ${ }^{5}$ MIT Haystack Observatory, Massachusetts, USA
}

Correspondence: Alan G. Wood (alan.wood@ntu.ac.uk)

Received: 2 August 2019 - Discussion started: 3 September 2019

Accepted: 11 December 2019 - Published: 24 April 2020

\begin{abstract}
Polar holes were observed in the high-latitude ionosphere during a series of multi-instrument case studies close to the Northern Hemisphere winter solstice in 2014 and 2015. These holes were observed during geomagnetically quiet conditions and under a range of solar activities using the European Incoherent Scatter (EISCAT) Svalbard Radar (ESR) and measurements from Global Navigation Satellite System (GNSS) receivers. Steep electron density gradients have been associated with phase scintillation in previous studies; however, no enhanced scintillation was detected within the electron density gradients at these boundaries. It is suggested that the lack of phase scintillation may be due to low plasma density levels and a lack of intense particle precipitation. It is concluded that both significant electron density gradients and plasma density levels above a certain threshold are required for scintillation to occur.
\end{abstract}

\section{Introduction}

The F-region ionosphere is a weakly ionised plasma in the Earth's atmosphere extending from an altitude of $\sim 150$ to $\sim 500 \mathrm{~km}$, above which it merges with Earth's plasmasphere. Large-scale plasma structures with a horizontal extent of tens to hundreds of kilometres are routinely observed in the F-region high-latitude ionosphere (Tsunoda, 1988). One type of structure commonly observed are polar cap patches, also referred to as patches, which are en- hancements of plasma density with at least twice the background value and a horizontal spatial extent of $100 \mathrm{~km}$ or more (Crowley, 1996). Buchau et al. (1983) observed such patches of enhanced ionisation drifting anti-sunward with the background plasma flow in the central region of the polar cap at Thule, Greenland: $77.5^{\circ} \mathrm{N}, 69.2^{\circ} \mathrm{W} ; 85.4^{\circ}$ MLAT (magnetic latitude), $32.4^{\circ} \mathrm{MLON}$ (magnetic longitude). The patch densities were larger than could be produced due to the observed flux of precipitating particles, and it was concluded that the patches were not produced locally by precipitation. Weber et al. (1984) suggested that the patches were produced on the dayside at auroral or sub-auroral latitudes and then convected anti-sunward to higher, polar latitudes. A comparison of average maps of the electron density and the high-latitude convection pattern suggested that solar-produced plasma was drawn into the polar cap as a continuous density enhancement known as the "tongue of ionisation" (TOI; Foster, 1984). Several mechanisms have been proposed to break a TOI into a series of patches, including variations in the high-latitude convection pattern moving flux tubes in and out of sunlight (Anderson et al., 1988), expansion and contraction of the high-latitude convection pattern in response to transient bursts of reconnection drawing in plasma from different latitudes (Cowley and Lockwood, 1992; Lockwood and Carlson, 1992; Carlson et al., 2002, 2004, 2006), variations in the $y$ component of the interplanetary magnetic field (IMF) drawing in plasma from different magnetic local times (MLT; Sojka et al., 1993), variation in 
the $z$ component of the IMF altering whether plasma could be drawn in to the polar cap (Valladares et al., 1998), erosion of plasma densities due to enhanced recombination during a flow channel event (Rodger et al., 1994; Valladares et al., 1994), and modification of the density of the photoionised plasma transported into the polar cap by particle precipitation (Walker et al., 1999; Millward et al., 1999). Patches have been observed travelling thousands of kilometres across the polar regions (Weber et al., 1986; Oksavik et al., 2010; Nishimura et al., 2014), and they are primarily associated with times when the $z$ component of the IMF is negative (Buchau and Reinisch, 1991).

Blobs are also plasma density enhancements; however, unlike patches, they occur outside the polar cap. They are further categorised into boundary blobs, sub-auroral blobs, and auroral blobs (Rino et al., 1983; Jin et al., 2016). Boundary blobs are found near the equatorward auroral boundary, neighbouring the ionospheric trough's poleward wall. Parkinson et al. (2002) observed patches leaving the polar cap, slowing in the anti-sunward direction and then beginning to move zonally. It was suggested that these patches would form boundary blobs; this was later confirmed by Pryse et al. (2006), who compared the plasma density in a polar cap patch to that within a boundary blob that the patch subsequently formed. Sub-auroral blobs have a similar appearance to boundary blobs; however, they are found in the ionospheric trough. Auroral blobs are found within the auroral oval and seem to be longitudinally restricted. The most likely mechanism for their creation is particle precipitation (Jones et al., 1997).

Not all ionospheric structures are enhancements of the background plasma; polar ionospheric holes are regions of low plasma density. Brinton et al. (1978) observed a depletion of this kind under low solar activity $(\mathrm{F} 10.7=71 \mathrm{sfu})$ and low magnetic activity $(\mathrm{Kp}=2)$ conditions. This depletion was also associated with a minimum of electron temperatures, indicating the absence of local particle precipitation. Polar holes are generally located between 21:00 and 06:00 MLT and between 70 and $80^{\circ}$ MLAT and typically have steep plasma density gradients at their boundaries. They are believed to be produced when plasma in the high-latitude convection pattern circulates in perpetual darkness. Plasma loss by recombination in the absence of a plasma source causes density levels to drop. This idea is supported by the conditions under which polar holes have generally been observed, namely quiet geomagnetic activity (Kp 2 or less) when the contribution to the plasma densities from particle precipitation is low (Brinton et al., 1978). The electron densities inside of the polar holes are seen to reach a minimum in the range of $10^{8}-10^{11}$ electrons $\mathrm{m}^{-3}$ (Obara and Oya, 1989; Benson and Grebowsky, 2001) and, while there is variation between holes, inside of a singular polar hole the density level is consistent.

Smaller-scale structures can arise at steep plasma density gradients due to instability processes such as the gra- dient drift instability (GDI) (Keskinen and Ossakow, 1983) and the velocity-shear-driven instability (Kelvin-Helmholtz instability, KHI). Carlson et al. (2008) proposed that the real process involves both mechanisms acting on different timescales. The smaller-scale (tens of metres to tens of kilometres) plasma density structures that arise cause variations in the refractive index of the ionosphere. As a GNSS signal passes through this region, refraction and/or diffraction of the radio wave causes fluctuations in the phase and amplitude of the signal. Ionospheric scintillation is the rapid fluctuation of the received signal which can disrupt applications using GNSS, as thoroughly reviewed by Hapgood (2017). Since the Second World War, large numbers of studies have shown the effect of ionospheric irregularities on radio signals, as reviewed by Aarons (1982). The morphology of these irregularities has been extensively studied at high latitudes (e.g. Kersley et al., 1972), along with the effects upon the propagation of radio signals in this region (e.g. Kersley et al., 1995).

More recently studies have focused on Global Navigation Satellite System (GNSS) frequencies, where scintillation poses a substantial threat to the integrity, availability, and accuracy of GNSS positioning, leading to positioning errors and service outages due to signal tracking problems at the GNSS receiver. A direct connection between gradients in the total electron content (TEC) at the edge of a plasma stream with both phase and amplitude scintillation has been observed (Mitchell et al., 2005), and plasma structuring caused by auroral precipitation has been linked to the loss of signal lock by a GNSS receiver (Elmas et al., 2011; Smith et al., 2008; Oksavik et al., 2015). A statistical study has shown an agreement between both phase and amplitude scintillation with the asymmetric distribution of polar cap patches around magnetic midnight (Spogli et al., 2009) and that auroral emissions correlate with GNSS signal phase scintillation (Kinrade et al., 2013; van der Meeren et al., 2015). Phase and amplitude scintillation can be associated with the larger spatial structures related to polar cap patches (Alfonsi et al., 2011). The climatology of ionospheric scintillation at polar latitudes in the Northern Hemisphere was determined over almost two solar cycles, and the dependence upon solar cycle, geomagnetic activity, and solar wind conditions was shown by De Franceschi et al. (2019). Phase scintillation is usually the dominant process at high latitudes (Spogli et al., 2009; Prikryl et al., 2015), and this is the focus of the present study.

Phase scintillation is commonly quantified by the standard deviation of the signal phase, $\sigma_{\varphi}$, which is usually computed over $60 \mathrm{~s}$. The refractive component of the signal is usually assumed to be slowly varying and associated with frequencies of less than $0.1 \mathrm{~Hz}$. Therefore, by only considering frequencies greater that $0.1 \mathrm{~Hz}$, the diffractive effects (usually referred to as scintillation) can be distinguished (Fremouw et al., 1978). However, the $0.1 \mathrm{~Hz}$ cutoff can give spurious observations of phase scintillation as a result of erroneous data 
detrending (Forte and Radicella, 2002). When a GNSS satellite is observed at low elevation angles, the $\sigma_{\varphi}$ index cannot distinguish between phase scintillation and background noise for weak to moderate phase scintillation (Forte, 2005). Wang et al. (2018) showed that rapid variations in the phase of a trans-ionospheric signal can arise as a result of plasma structures moving rapidly relative to an observer at ground level and can therefore give the appearance of phase scintillation. Rapid changes in the spatial distribution of electron density can also introduce similar effects, as the GNSS satellite-toreceiver ray path can sweep through these irregularities at high speed, resulting in high-frequency refractive variations (McCaffrey and Jayachandran, 2019).

The presence or absence of scintillation effects on transionospheric radio signals have been extensively studied for electron density enhancements in the high-latitude ionosphere; however, the effect of the steep plasma density gradients at the edge of depletions, such as polar holes, has not been as comprehensively considered. The purpose of this paper is to report on the effects of such steep density gradients on GNSS signals, observed in three multi-instrument case studies close to northern winter solstice, and to provide observational evidence that supports the work of Aarons (1982).

\section{Instrumentation}

The European Incoherent Scatter Scientific Association (EISCAT) operates the EISCAT Svalbard Radar (ESR) at Longyearbyen $\left(78.2^{\circ} \mathrm{N}, 16.0^{\circ} \mathrm{E} ; 15.2^{\circ} \mathrm{MLAT}\right.$, $112.9^{\circ} \mathrm{MLON}$ ) on Svalbard (Wannberg et al., 1997). The site consists of two antennas, a $32 \mathrm{~m}$ parabolic dish, and a $42 \mathrm{~m}$ parabolic dish. The $42 \mathrm{~m}$ dish is fixed along the direction of the local geomagnetic field lines (azimuth $-179^{\circ}$; elevation $81.6^{\circ}$ ), whereas the $32 \mathrm{~m}$ dish is steerable with respect to both azimuth and elevation. Observations of the electron density, electron temperature, ion temperature, and ion drift line of sight velocity in the ionosphere from this incoherent scatter radar (ISR) are used in this study.

The Super Dual Auroral Radar Network (SuperDARN) is a network of high-latitude coherent scatter radars (Greenwald et al., 1995; Chisham et al., 2007; Nishitani et al., 2019) that observe line-of-sight plasma velocities in the $\mathrm{F}$ region. These measurements are assimilated using the map potential technique (Ruohoniemi and Baker, 1998), which uses an ionospheric convection model to map the electrostatic potential pattern. Electrostatic equipotential lines are streamlines of ionospheric convection flows. As the plasma drift velocity is perpendicular to both the electric and magnetic fields in the $\mathrm{F}$ region $(\boldsymbol{E} \times \boldsymbol{B}$ drift), the plasma convection pattern can be directly inferred from the electric potential maps.

GNSS signals detected by NovAtel GPStation- 6 receivers at the Kjell Henriksen Observatory (KHO; $78.2^{\circ} \mathrm{N}, 16.0^{\circ} \mathrm{E}$; $15.2^{\circ}$ MLAT, $112.9^{\circ} \mathrm{MLON}$ ) can be used to infer the ef-

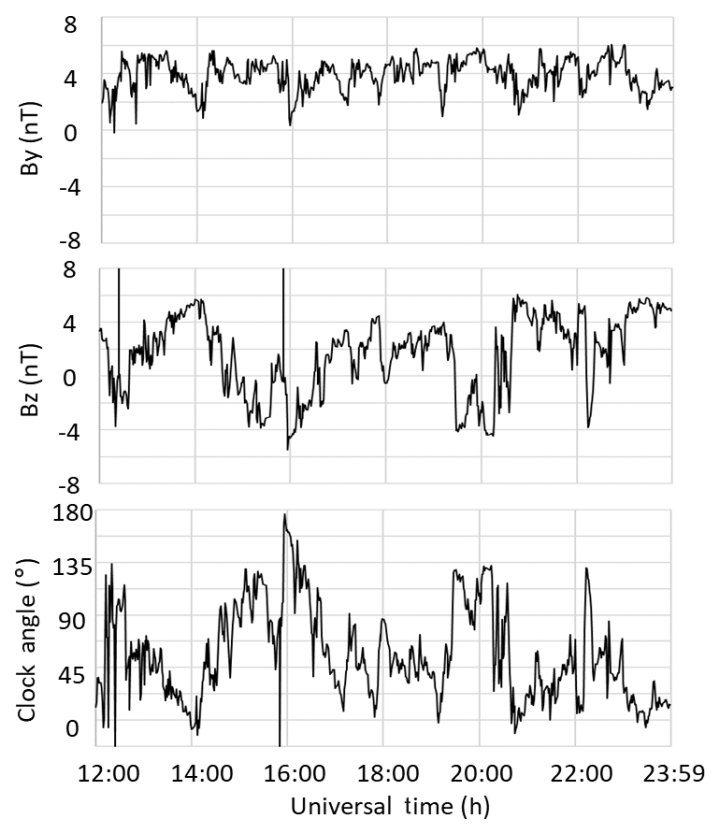

Figure 1. The $y$ and $z$ components of the IMF, and the clock angle observed by the ACE spacecraft between 12:00 and 23:59 UT on 17 December 2014. The data have been time-shifted to the nose of the Earth's bow shock.

fects of the ionosphere on radio waves travelling though this medium. Amplitude scintillation is measured using the $S_{4}$ index, which is the square root of the variance of received power divided by the mean value of the received power (Briggs and Parkin, 1963). Phase scintillation is measured using the $\sigma_{\phi}$ index, which is the standard deviation of the detrended carrier phase $\phi$ in radians (Fremouw et al., 1978) over $60 \mathrm{~s}$.

The IMF was observed by the Advanced Composition Explorer (ACE), which is a NASA spacecraft orbiting the L1 Lagrangian point of the Earth-Sun system, roughly $1.54 \times$ $10^{6} \mathrm{~km}$ from the Earth (Zwickl et al., 1998). In addition to the $x, y$, and $z$ components of the IMF, the clock angle, given by $\arctan \frac{\left|B_{y}\right|}{B_{z}}$, is also considered. When the clock angle is greater than $45^{\circ}$ either $\left|B_{y}\right|>\left|B_{z}\right|$ or $B_{z}<0$; in either case a two-cell convection pattern is expected with anti-sunward flow drawing plasma from day to night across the polar cap (Thomas and Shepherd, 2018).

Total electron content (TEC) maps are used to put these measurements into context. These were obtained from the Madrigal database at the MIT Haystack Observatory (Rideout and Coster, 2006; Vierinen et al., 2016). Two other indices are used within this study: the $\mathrm{Kp}$ index is used as a proxy for disturbances to the geomagnetic field, and the $\mathrm{F} 10.7 \mathrm{~cm}$ solar flux is used as a proxy for solar activity. These indices were both obtained from the UK Solar System Data Centre (UKSSDC) at the Rutherford Appleton Laboratory, UK. 


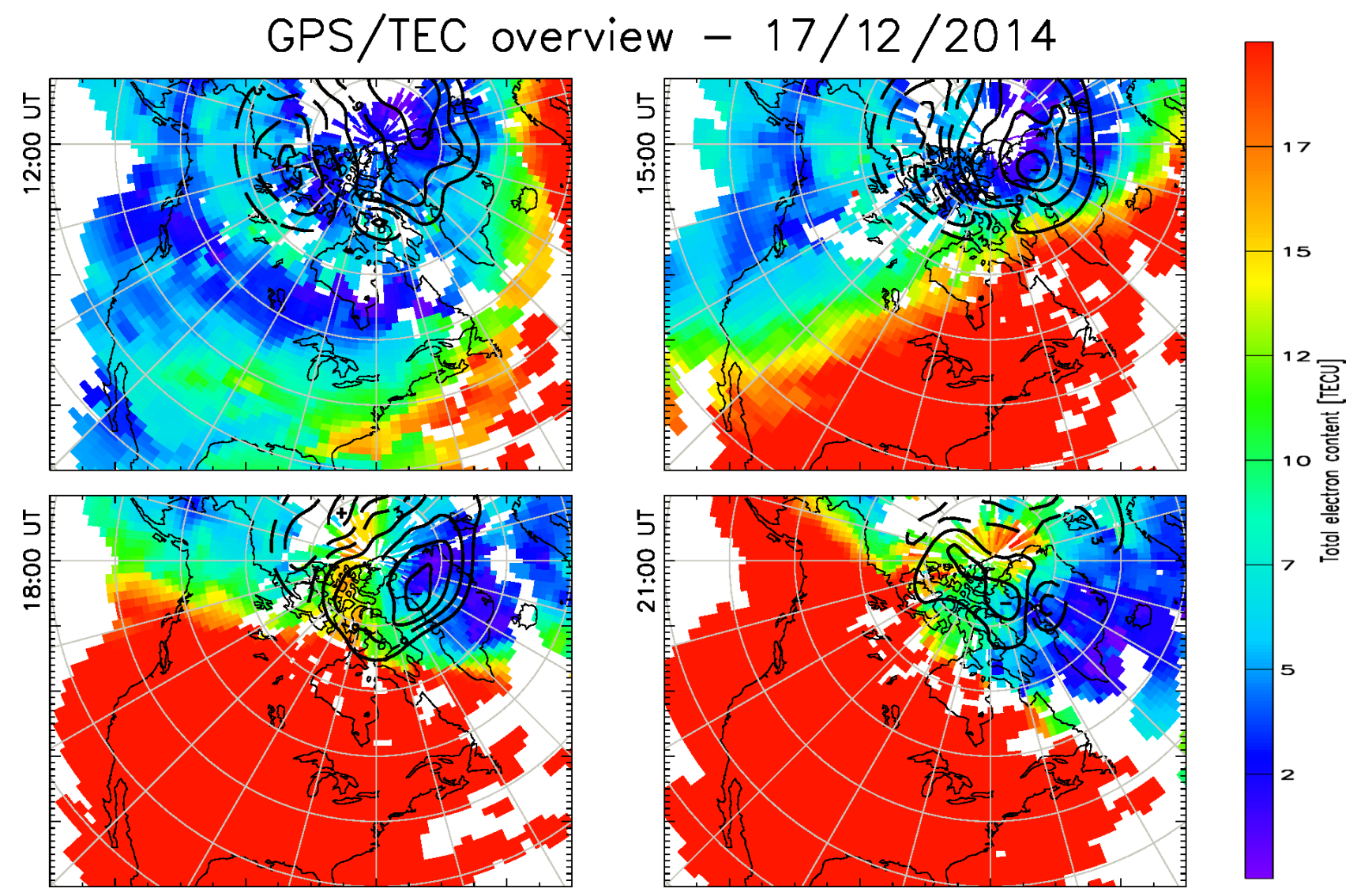

Figure 2. TEC maps for 17 December 2014 extrapolated from TEC collected by a network of GNSS receivers at 3-hourly intervals between 12:00 and 21:00 UT.

\section{Results}

\subsection{Case study: 17 December 2014}

The 3-hourly Kp values observed on 17 December 2014 between 12:00 and 23:59 UT ranged between $1-$ and $1+$, indicating quiet conditions. The F10.7 cm solar flux was relatively high; the value of $198.5 \mathrm{sfu}$ is typical of solar maximum. The IMF observed by the ACE spacecraft between 12:00 and 23:59 UT (Fig. 1) was characterised by a positive value for the IMF $B_{y}$ (mean value $3.9 \mathrm{nT}$ ). IMF $B_{z}$ was more variable but generally showed smaller values (mean value of $1.7 \mathrm{nT}$ ). The clock angle was generally greater than $45^{\circ}$ from 14:00 to 19:00 UT, and the corresponding SuperDARN plots (discussed later in this section) show that a two-cell convection pattern dominated until at least 20:00 UT.

Total electron content (TEC) maps (Fig. 2) show the overall plasma density throughout the high-latitude regions. The TEC maps at 12:00 and 15:00 UT display values of $\sim 2 \mathrm{TECu}$ (dark blue) in the polar cap. At 18:00 UT and 21:00 UT larger electron densities can be observed crossing the polar cap in a two-cell convection pattern, with values of $\sim 15 \mathrm{TECu}$ (yellow), indicating that plasma produced by photoionisation on the dayside is being drawn into the polar cap.

The electron densities and temperatures observed by the field-aligned $42 \mathrm{~m}$ dish of the EISCAT Svalbard Radar (ESR) between 12:00 and 23:59 UT are shown in Fig. 3. The scales for this plot have been chosen to enable a clear comparison with other figures presented in this paper. A clear depletion in the electron densities is observed between approximately 16:00 and 18:00 UT at all altitudes. The electron and ion temperatures are not elevated at this time with values of approximately $1000 \mathrm{~K}$, suggesting that this depletion is void of particle precipitation and did not arise from enhanced recombination due to Joule heating. The ESR does not show a substantial plasma velocity aligned with the radar beam. This radar observed at an elevation of $81.6^{\circ}$, which is aligned with the magnetic field line in the $\mathrm{F}$ region. There was no substantial component of velocity observed along the magnetic field line. In order to further investigate the electron density depletion, a line plot of the maximum detected electron density from 90 to $400 \mathrm{~km}$ is shown (Fig. 4). In addition to the maximum density, two other values are present on the plot: the average value for the whole day and $35 \%$ of the average value. The depletion was defined as the time when the electron den- 

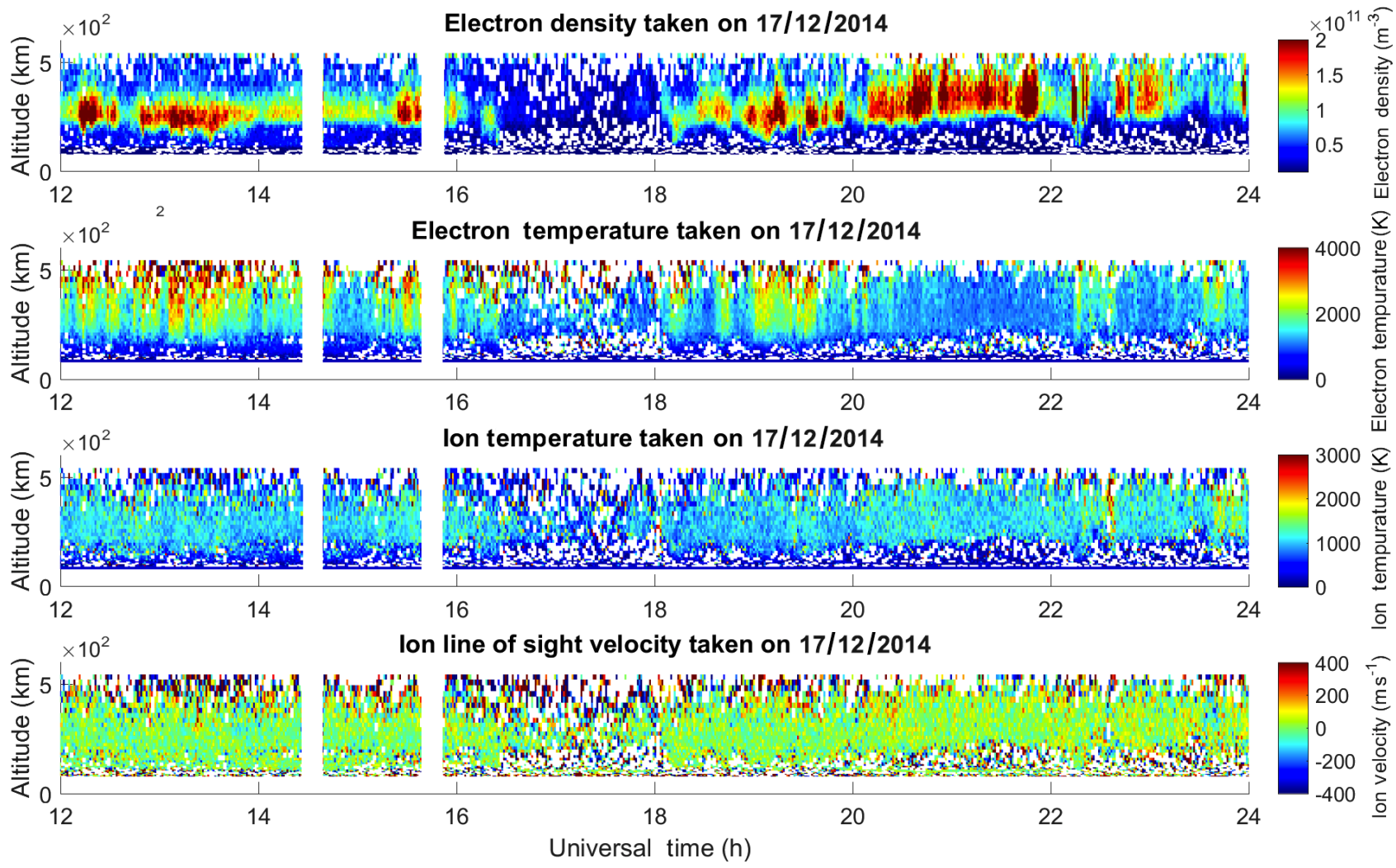

Figure 3. Electron densities, electron temperatures, ion temperatures, and ion drift line of sight velocity measured by the $42 \mathrm{~m}$ dish of the ESR observing at an azimuth of $184.5^{\circ}$ and an elevation of 81.6 between 12:00 and 23:59 UT on 17 December 2014.

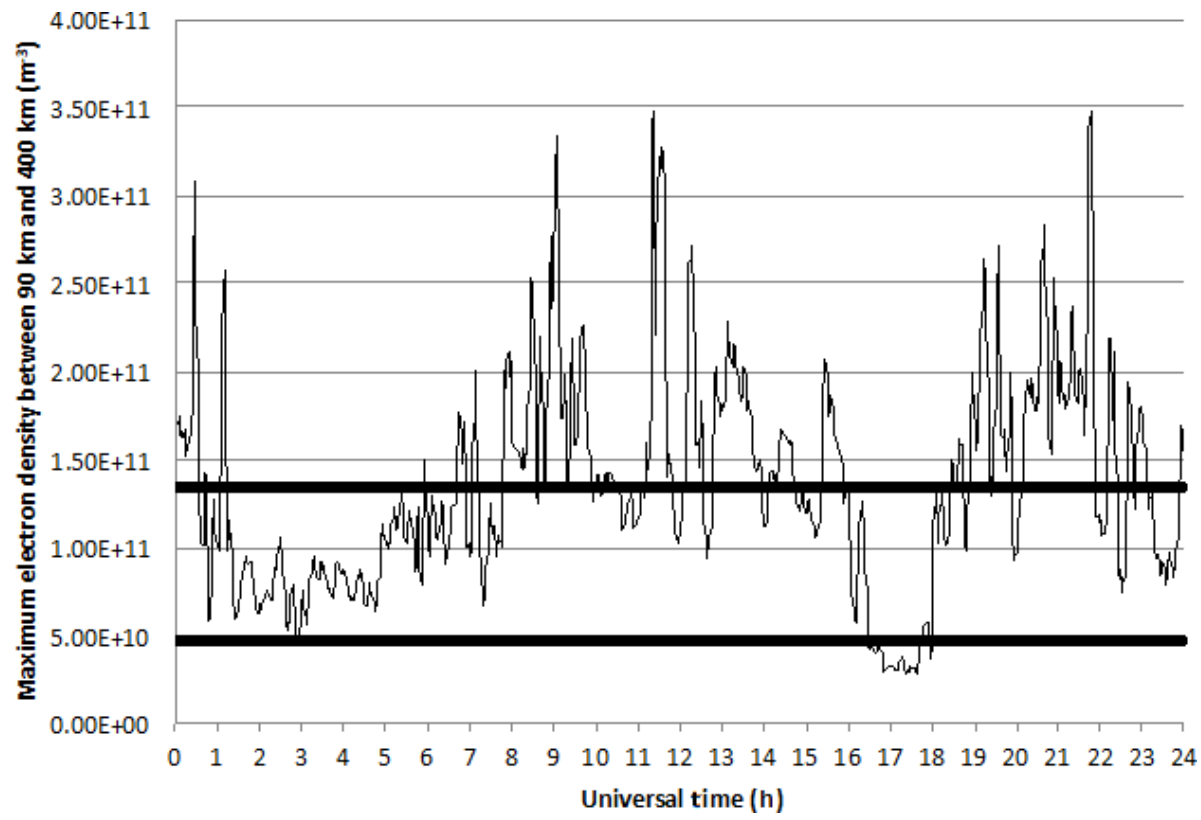

Figure 4. Maximum electron density between 90 and $400 \mathrm{~km}$ for the ESR $42 \mathrm{~m}$ observation on the 17 December 2014 at a 1 min resolution. A five point running mean was applied to these data. The upper horizontal line is the average value, and the lower horizontal line is $35 \%$ of the average. A polar hole can be seen between 16:29 and 18:00 UT. 


\section{SuperDARN parameter plot Convection maps (1200_2358_1x1)}

(a)

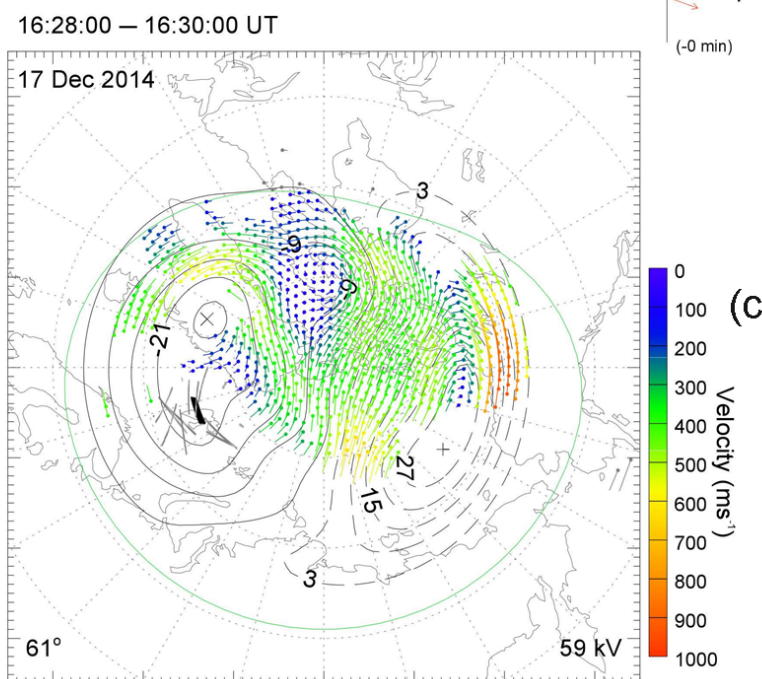

$1000 \mathrm{~ms}^{-1}$

$n=1291$

(c)
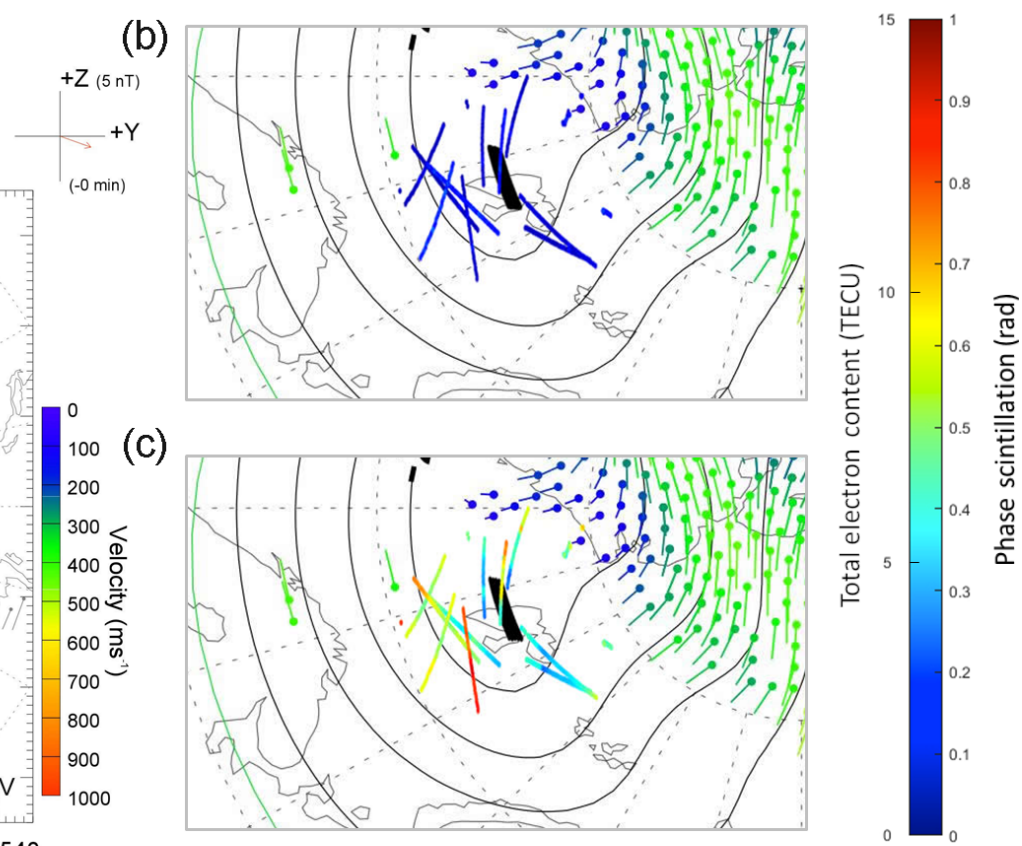

SuperDARN parameter plot

Convection maps (1200_2358_1x1)

(d)

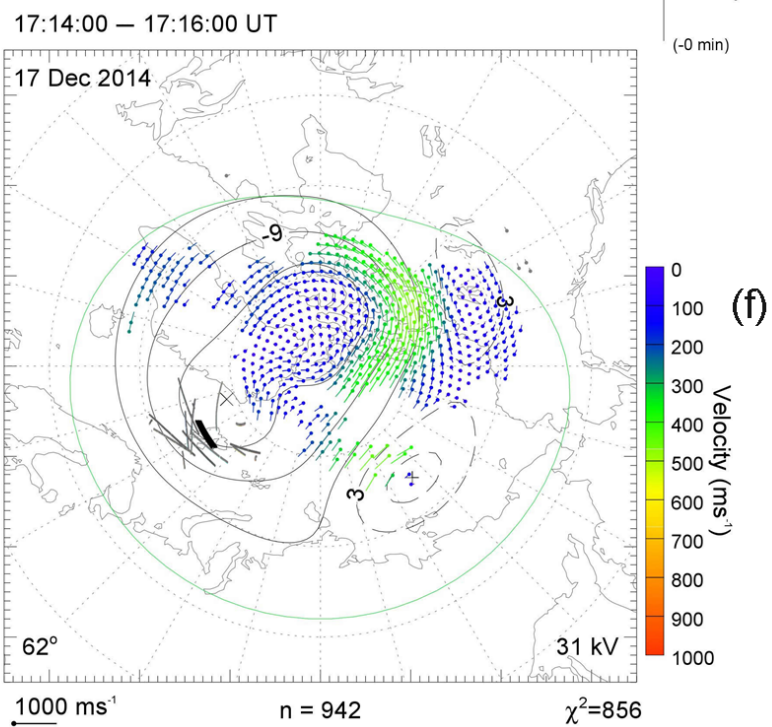

(e)

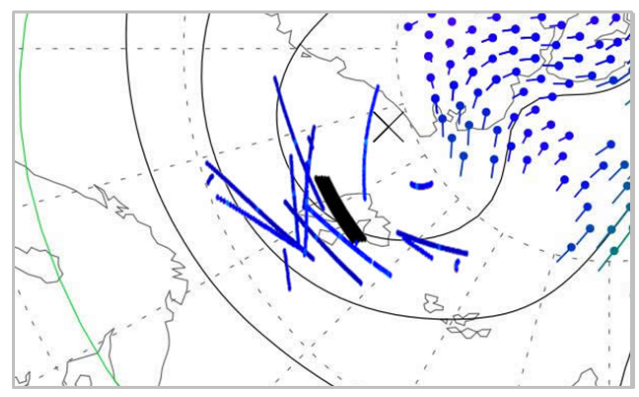

(f)

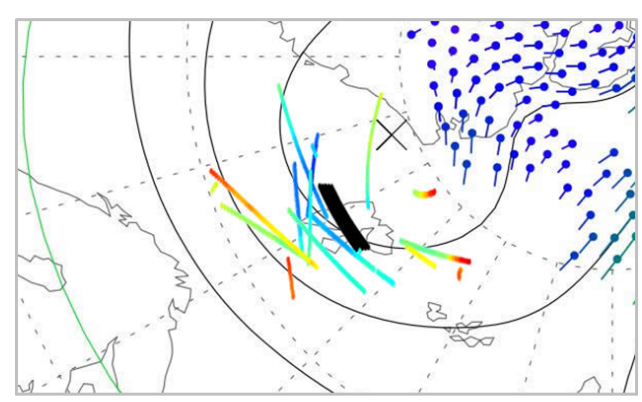

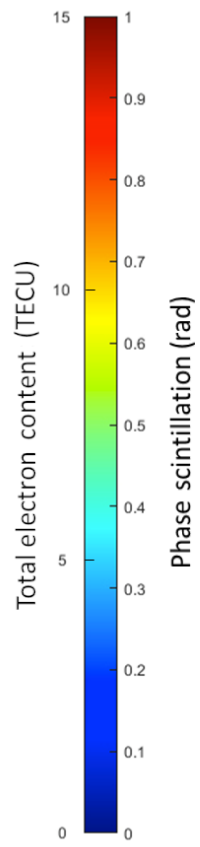

Figure 5. 


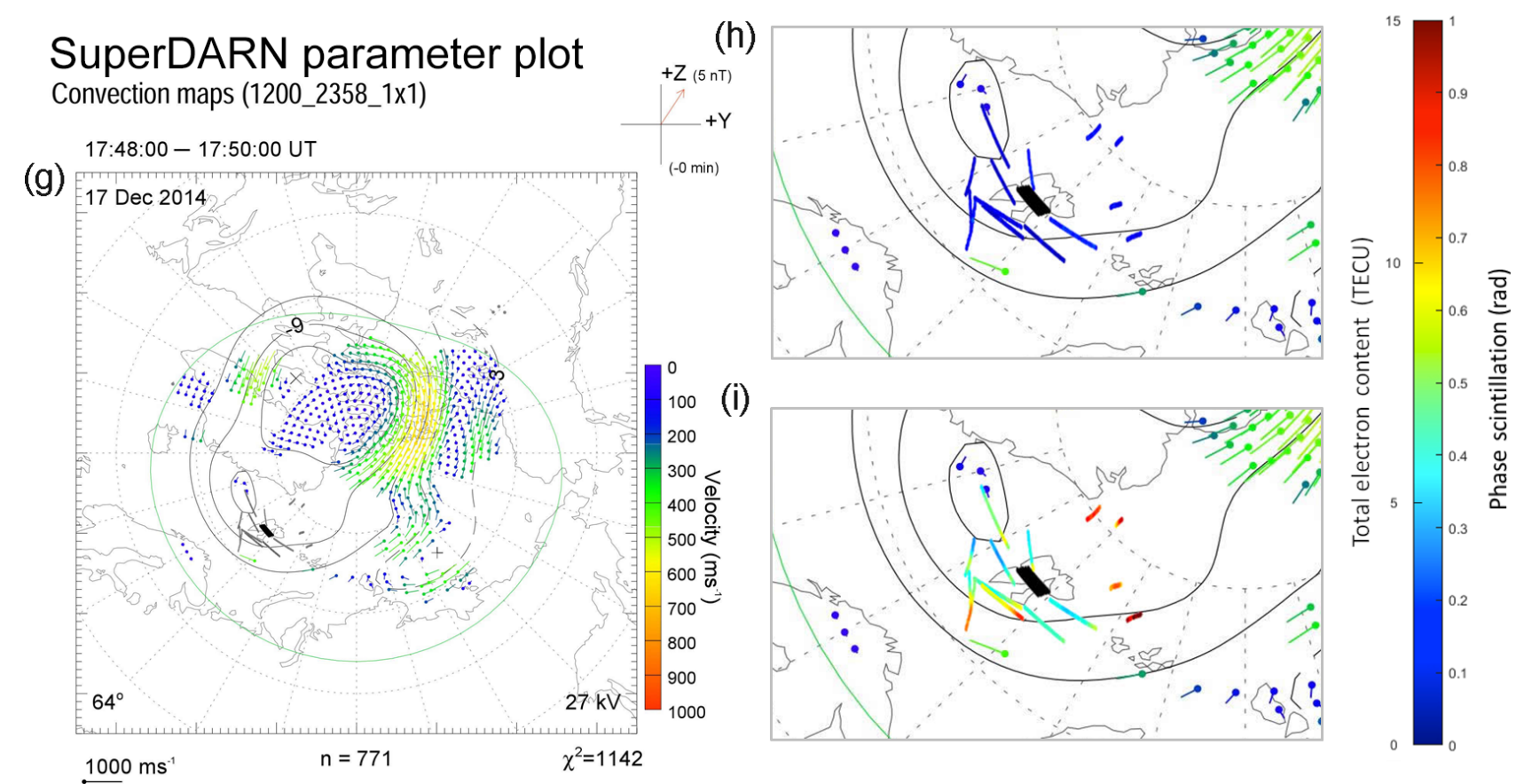

Figure 5. Electric potential patterns inferred from the SuperDARN radars for 16:28, 17:14, and 17:48 UT on 17 December 2014 as a function of geomagnetic latitude and magnetic local time. Magnetic noon is shown at the top of panels (a), (d), and (g), with dusk and dawn on the left- and right-hand sides respectively and magnetic midnight at the bottom. Magnetic latitude is indicated by the grey dashed circular lines at $10.0^{\circ}$ increments. The grey lines show the location of satellite passes from GNSS satellites, assuming an ionospheric intersection of $350 \mathrm{~km}$. The SuperDARN plot from 16:28 UT includes satellite passes from 16:00 to 16:58 UT, the 17:14 UT plot includes satellite passes from 16:58 to 17:28 UT, and the 17:48 UT plot includes satellite passes from 17:28 to 18:02 UT. These time intervals were chosen as the inspection of the whole SuperDARN data set at a 2 min resolution indicated that the convection patterns were relatively stable during these intervals. Panels (b), (c), (e), (f), (h), and (i) show the area around the satellite passes in more detail. Colours represent phase scintillation (b, e, h) and TEC $(\mathbf{c}, \mathbf{f}, \mathbf{i})$. The thick black line indicates the position of the polar hole observed using the $42 \mathrm{~m}$ dish of the EISCAT Svalbard Radar.

sity dropped below the $35 \%$ line; in this case, the depletion was defined as starting at 16:29 UT and ending at 18:00 UT.

Figure 5 shows the high-latitude convection pattern inferred from the SuperDARN radars for three representative times during the period that the electron density depletion was observed by the ESR. These clearly show a two-cell convection pattern, with plasma drawn anti-sunward across the polar cap. The ESR observes at a given location, which rotates under the convection pattern. The depletion, identified in Fig. 4, is indicated by a black line. At midwinter, Svalbard is in perpetual darkness. On 14 December, the ground-level terminator is at a maximum latitude of $68^{\circ} \mathrm{N}$, which corresponds to a maximum magnetic latitude of $76^{\circ}$ MLAT at 21:00 UT. The observed depletion is nightward of the terminator, and the SuperDARN convection patterns suggest that this plasma is circulating in perpetual darkness. It is interpreted as a polar hole.

The data collected by the GNSS receiver were from the GPS, Galileo, and GLONASS systems, and the receiver provided the azimuth and elevation of the satellite with respect to the receiver. This was converted into a latitude and longitude using the radio wave path and assuming that the data correspond to $350 \mathrm{~km}$ in altitude, in line with previous studies (e.g. Cervera and Thomas, 2006; Forte and Radicella, 2002). At low elevation angles, the GNSS TEC and scintillation data can become unreliable due to multi-path issues; thus, observations at an elevation of less than $30^{\circ}$ were discarded. This cutoff has been used in previous studies, such as Mitchell et al. (2005). Signal lock times below 240 s were also discarded, in line with previous studies (e.g. van der Meeren et al., 2015). The satellite tracks were overlaid onto SuperDARN plots (Fig. 5).

TEC and phase scintillation data from GNSS receivers were taken during times when the polar hole was observed. This hole is observed for $1.5 \mathrm{~h}$, and several satellite paths are present during this time window. The GNSS TEC data clearly show lower TEC levels at and around the area marked by the ESR as a hole, and, on some of the satellite trajectories, sharp changes can be seen with the edge of the hole. A one-to-one correspondence between the GNSS TEC data and the EISCAT data is neither expected nor observed. It is highly likely that the polar hole will evolve during the time for which it is observed; therefore, the plots in Fig. 5 include both spatial and temporal variation. The ESR observes the 


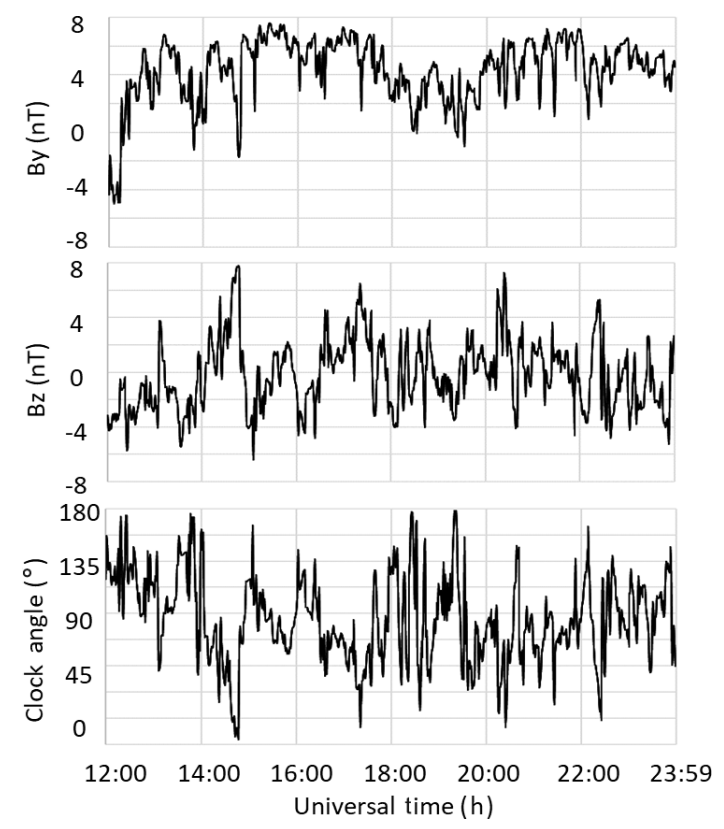

Figure 6. The $y$ and $z$ components of the IMF as well as the clock angle observed by the ACE spacecraft between 12:00 and 23:59 UT on 10 December 2015, shown in the same format as Fig. 1. The data have been time-shifted to the nose of the Earth's bow shock.

polar hole for $91 \mathrm{~min}$, and the plasma velocity inferred from the electric potential patterns inferred from the SuperDARN radars (Fig. 5) at this location is of the order of $150 \mathrm{~m} \mathrm{~s}^{-1}$; this indicates that the polar hole has a horizontal extent of some $800 \mathrm{~km}$ in a direction parallel to the plasma flow. In summary, the combination of the EISCAT, GNSS TEC, and SuperDARN measurements indicate that the polar hole is present for an extended period of time (of the order of hours) over a large spatial scale (hundreds of kilometres).

Panels showing the location of phase scintillation on the satellite tracks are also displayed in Fig. 5. A threshold of $0.2 \mathrm{rad}$ was used to identify phase scintillation. Different authors have used different thresholds for phase scintillation, including $0.2 \mathrm{rad}$ (e.g. van der Meeren, 2015), $0.25 \mathrm{rad}$ (e.g. Alfonsi et al., 2011), and $0.3 \mathrm{rad}$ (e.g. Kinrade et al., 2013). The purpose of using a low threshold within the present study was to ensure that any possible indication of phase scintillation was included. As TEC and scintillation are collected simultaneously, comparing the two might be expected to show increased scintillation where there are changes in TEC. No scintillation was observed on the edges of the holes.

\subsection{Case study 2: 10 December 2015}

The F10.7 cm solar flux for this case was lower than in the first study, with a value of $108.5 \mathrm{sfu}$. The $\mathrm{Kp}$ index was higher, with a value of 3 from 12:00 to 18:00 UT and a value of 4 at 21:00 and 24:00 UT, indicating an active state, but not storm levels. Once again the IMF (Fig. 6) was variable, with $B_{z}$ taking positive and negative values. $B_{y}$ was consistently larger than $B_{z}$ and was dominant. As in the previous case study, a two-cell convection pattern was observed.

The TEC maps at 18:00 and 21:00 UT are shown in Fig. 7. As in the previous case study, these maps indicate higher density plasma produced at lower latitudes being drawn across the polar cap within the high-latitude convection pattern, with this effect maximising at 21:00 UT.

The $42 \mathrm{~m}$ ESR observations (Fig. 8) for this day show an electron density depletion that contains all of the previously discussed markers, with no significant velocity in the fieldaligned direction.

Using the same method as in the previous case, the hole was identified, with the start and end times given as 15:15 and 16:43 UT respectively (Fig. 9). The $32 \mathrm{~m}$ ESR (Fig. 10) observations show a depletion at around 15:00 UT.

The high-latitude convection pattern was inferred from the SuperDARN radars (Fig. 11), with the location of the polar hole observed in the $42 \mathrm{~m}$ ESR observations and GNSS TEC and phase scintillation measurements overlaid as in the previous case study. The $32 \mathrm{~m}$ ESR observations (Fig. 10) were directed poleward, indicating that this is a polar hole rather than the ionospheric trough, which would be located equatorward of the radar. A substantial plasma velocity of some $300 \mathrm{~m} \mathrm{~s}^{-1}$ towards the radar was observed at 16:00 UT, indicating crosspolar flow in the equatorward direction. The high-latitude convection pattern inferred from the SuperDARN radars also shows anti-sunward cross-polar flow but with a more asymmetric convection pattern than was observed on 17 December 2014. On 10 December 2015 there was a clear dominant dusk cell, drawing plasma across the polar cap from the prenoon sector. The polar hole observed with the $42 \mathrm{~m}$ dish of the ESR was in the sunward return flow in the dusk convection cell.

The phase scintillation plot for 15:16 to 16:14 UT (Fig. 11b) has some satellite trajectories passing through the hole boundary but displays no significant scintillation on any of the paths. The later plot (Fig. 11e) does contain phase scintillation, although none of the elevated scintillation matches up to hole boundaries; instead, the scintillation is seen in regions of high and elevated electron density.

\section{Discussion}

A series of polar ionospheric holes have been detected in the high-latitude nightside ionosphere in case studies close to winter solstice, under varying solar intensities and geo- 


\section{GPS/TEC overview - 10/12/2015}
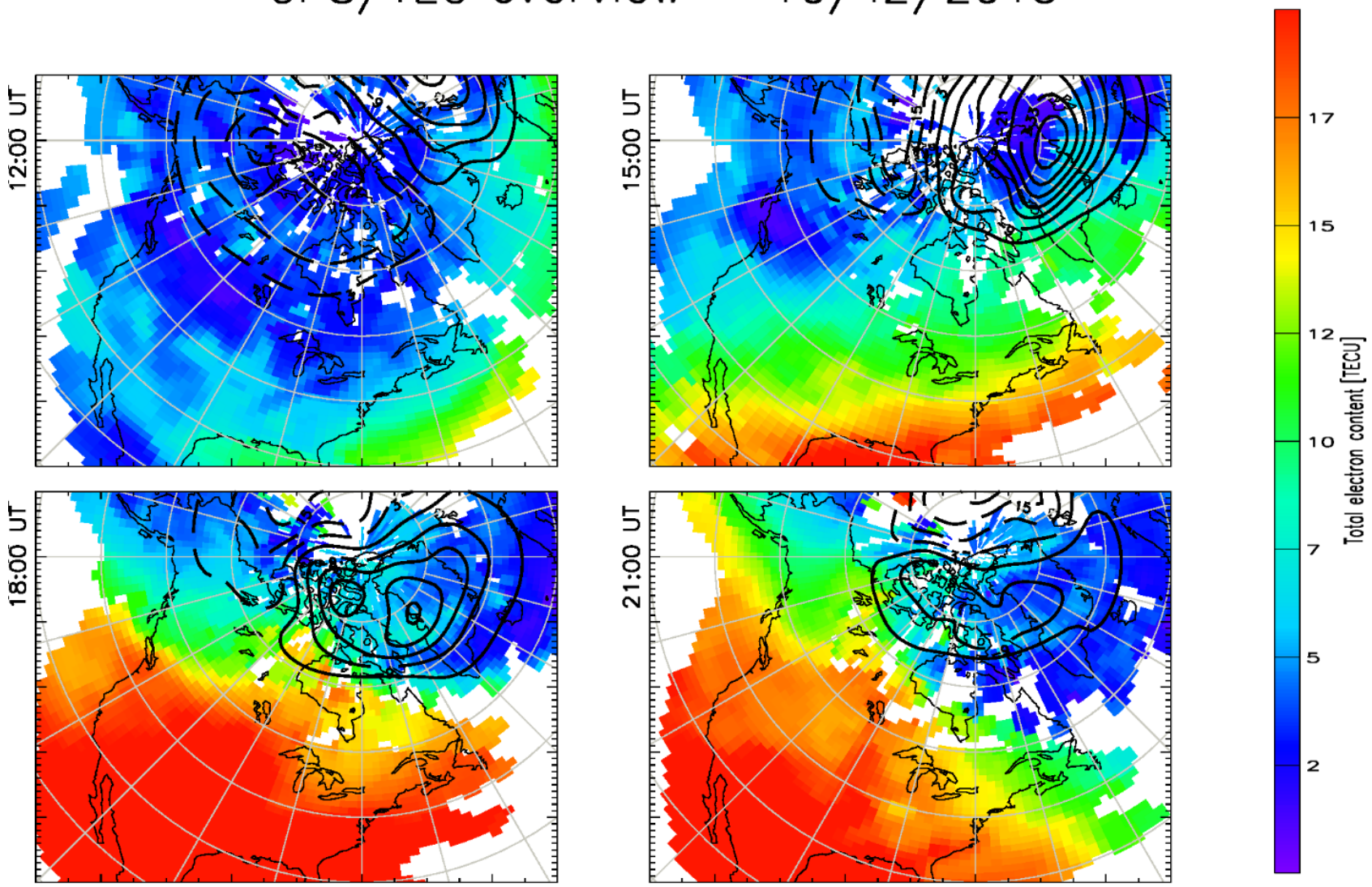

Figure 7. TEC maps for 10 December 2015 extrapolated from TEC collected by a network of GNSS receivers at 3-hourly intervals between 12:00 and 21:00 UT.

Table 1. The electron density gradient at each edge of the polar hole, and the average electron density inside the hole at $350 \mathrm{~km}$ observed by the ESR $42 \mathrm{~m}$.

\begin{tabular}{lrrr}
\hline Date & $\begin{array}{r}\text { First edge } \\
\left(\Delta N_{\mathrm{e}} \mathrm{m}^{-3} \mathrm{~h}^{-1}\right)\end{array}$ & $\begin{array}{r}\text { Second edge } \\
\left(\Delta N_{\mathrm{e}} \mathrm{m}^{-3} \mathrm{~h}^{-1}\right)\end{array}$ & $\begin{array}{r}\text { Average hole } \\
\left(N_{\mathrm{e}} \mathrm{m}^{-3}\right)\end{array}$ \\
\hline 17 Dec 2014 & $1.0 \times 10^{11}$ & $0.91 \times 10^{11}$ & $0.40 \times 10^{11}$ \\
10 Dec 2015 & $3.5 \times 10^{11}$ & $1.6 \times 10^{11}$ & $0.22 \times 10^{11}$ \\
12 Dec 2015 & $0.79 \times 10^{11}$ & $1.0 \times 10^{11}$ & $0.18 \times 10^{11}$ \\
\hline
\end{tabular}

magnetic disturbance levels. The first study on 17 December 2014 was characterised by high levels of solar activity (198.5 sfu) and quiet geomagnetic conditions. The second case study on 10 December 2015 also had lower levels of solar activity of (108.5 sfu) but had more active geomagnetic conditions $(\mathrm{Kp}=3)$ than in the previous study. A third case study conducted under quiet geophysical conditions $(\mathrm{Kp} \leq 2)$ and moderate solar activity (F10.7 cm solar flux $=116.7 \mathrm{sfu})$ on 12 December 2015 showed similar results (not shown).

Ionospheric polar holes contain much lower electron densities than those detected during the rest of the day. This study used the time when the maximum density at a given time dropped $35 \%$ below the daily average maximum density to identify these holes. The changes in electron density are associated with large electron density gradients. Table 1 shows the electron density gradients and the average hole electron density, based on observations from the ESR $42 \mathrm{~m}$. The average polar hole density observed in this study is comparable to those previously reported of $10^{8}$

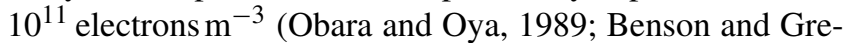
bowsky, 2001). Steep electron density gradients are observed at the edges of the holes (these are expressed in units of $\left.\Delta N_{\mathrm{e}} \mathrm{m}^{-3} \mathrm{~h}^{-1}\right)$. Although these gradients are expressed in units of per hour $\left(\mathrm{h}^{-1}\right)$, they were calculated from successive observations by the ESR $42 \mathrm{~m}$ (these measurements are typically $1 \mathrm{~min}$ apart). The spatial extent of these holes was at least several hundred kilometres, as inferred from the GNSS TEC measurements (all studies) and the ESR $32 \mathrm{~m}$ observations (case study from 17 December 2014). Polar holes are usually associated with quiet geomagnetic conditions $(\mathrm{Kp}<2)$. It is notable that, on 10 December 2015, a polar hole was observed under more active geomagnetic conditions $(\mathrm{Kp}=3)$. 

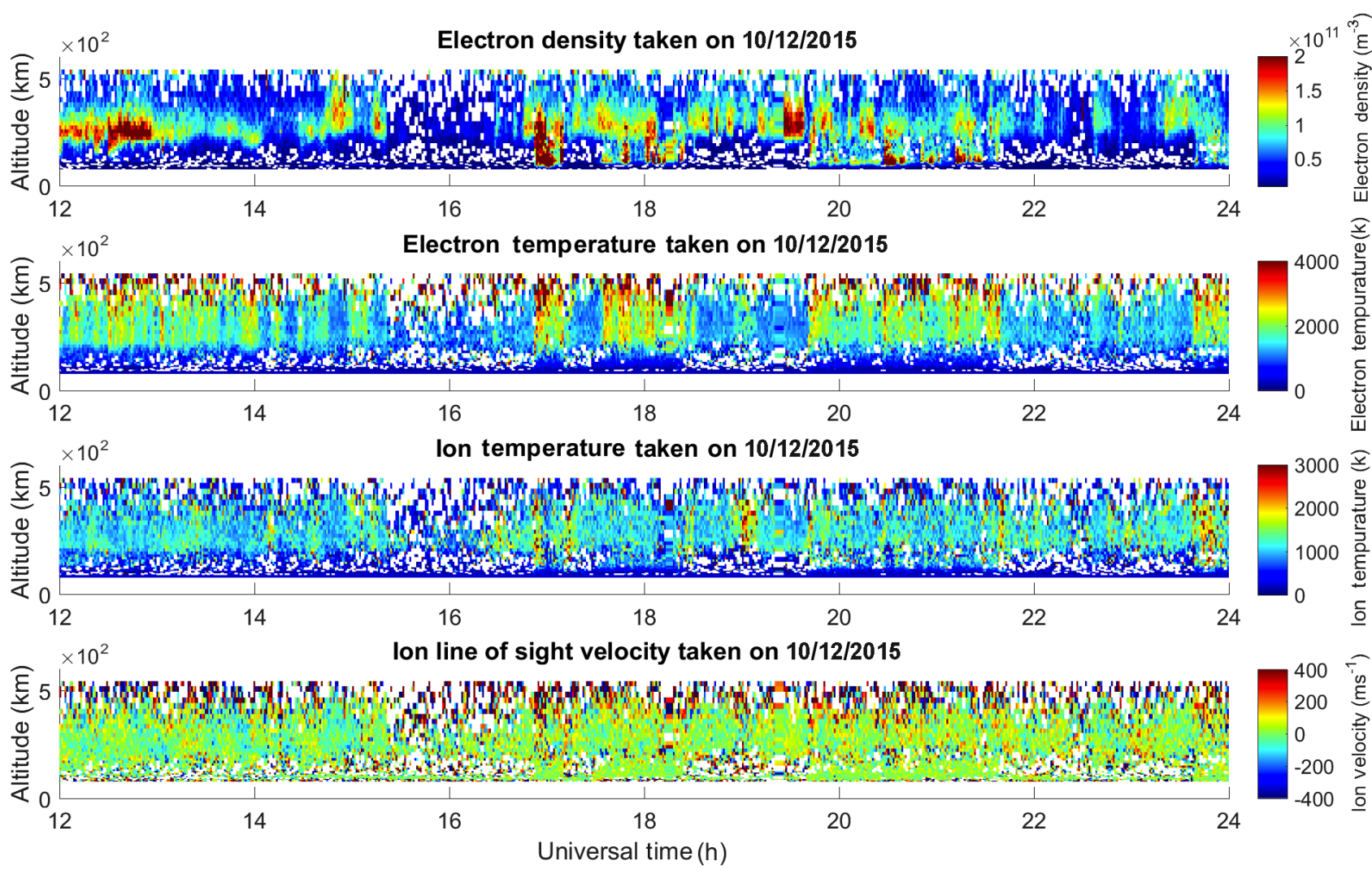

Figure 8. Electron densities, electron temperatures, ion temperatures, and ion drift line of sight velocity measured by the $42 \mathrm{~m}$ dish of the ESR observing at an azimuth of $184.5^{\circ}$ and an elevation of $81.6^{\circ}$ between 12:00 and 23:59 UT on 10 December 2015.

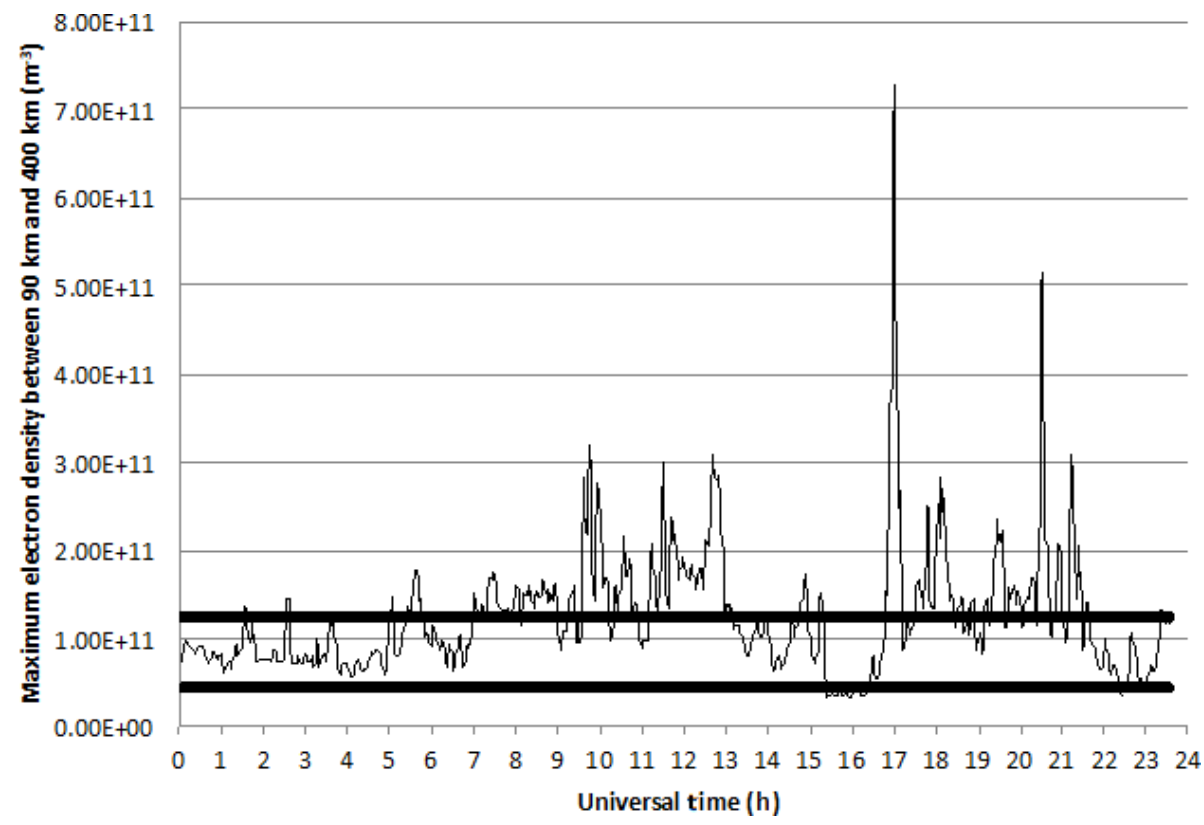

Figure 9. As in Fig. 4 but for 10 December 2015. A polar hole can be seen between 15:24 and 16:25 UT. 

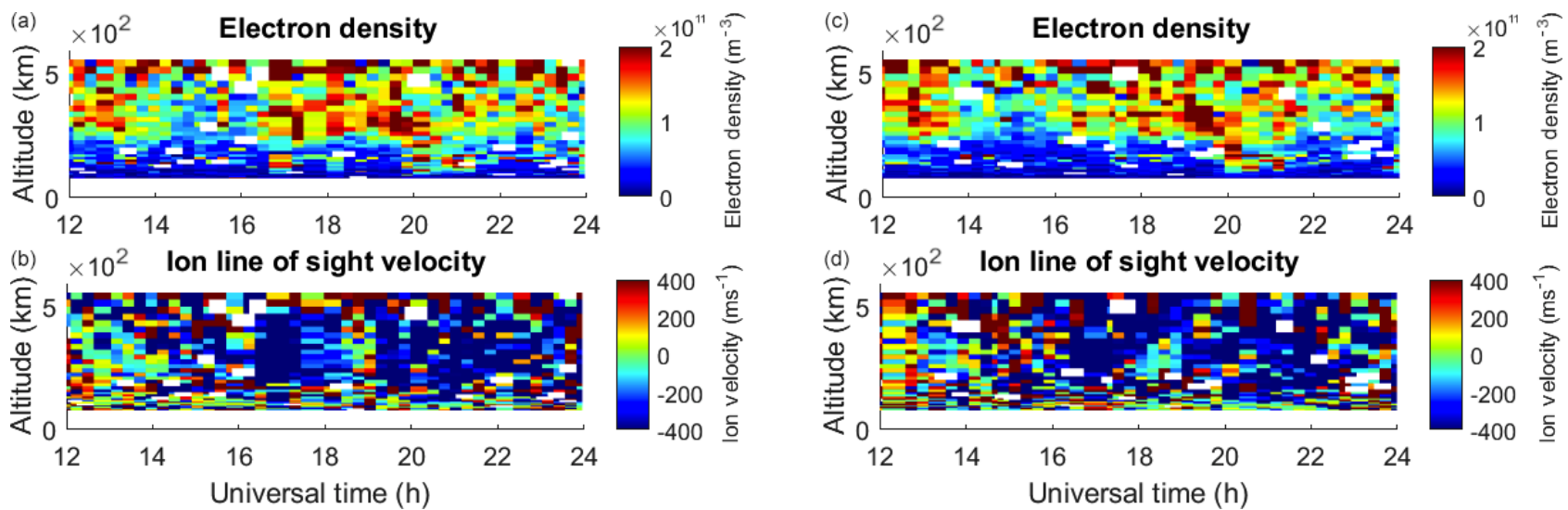

Figure 10. Electron densities and ion drift line of sight velocities observed by the $32 \mathrm{~m}$ dish of the ESR at $-43^{\circ}$ azimuth and $30^{\circ}$ elevation (a, b) and at $-14^{\circ}$ azimuth and $30^{\circ}$ elevation (c, d) between 12:00 and 23:59 UT on 10 December 2015 .

The IMF conditions during the time when the polar holes were observed, and for several hours beforehand, were appropriate for anti-sunward cross-polar convection. The ground-level solar terminator for winter is only above $70^{\circ}$ MLAT between 15:00 UT and slightly after 21:00 UT, reaching a maximum latitude of just under $76^{\circ}$ MLAT on the dayside at around 21:00 UT, creating the possibility that plasma within the high-latitude convection pattern could circulate in perpetual darkness; thus, the plasma undergoes recombination whilst simultaneously being insulated from photoionisation, or precipitation, creating a polar hole.

Phase scintillation has previously been observed to coincide with large plasma gradients such as on the edge of ionospheric enhancements, including polar cap patches (Jin et al., 2017), the tongue of ionisation (van der Meeren et al., 2014), plasma structures associated with the aurora (Kinrade et al., 2013; Oksavik et al., 2015; van der Meeren et al., 2015), and the mid-latitude trough (Pryse et al., 1991). The structures that cause scintillation arise due to the gradient drift instability and/or the Kelvin-Helmholtz instability (Keskinen and Ossakow, 1983; Carlson et al., 2008). In the present study, once the boundaries and the large electron density gradients associated with them were identified, these boundaries were investigated for elevated levels of phase scintillation. A threshold of $0.2 \mathrm{rad}$ was used; the purpose of this low value was to ensure that any possible indication of phase scintillation was included. Across all of the observed GNSS points coinciding with the polar hole boundaries, no such levels of phase scintillation were detected. Phase scintillation usually dominates at high latitudes (e.g. Prikryl et al., 2015), although amplitude scintillation has also been observed (e.g. Mitchell et al., 2005). The present study focuses upon phase scintillation as no amplitude scintillation, defined as when the $S_{4}$ index was greater than 0.2 , was observed on any of the TEC gradients at the boundaries of the polar holes.

This is not the first time a plasma density enhancement has been observed without corresponding phase scintilla- tion. The study by van der Meeren et al. (2016) reported a Sun-aligned polar cap arc under quiet geomagnetic conditions without corresponding scintillation. In the present study, some phase scintillation was observed; however, these points coincide with increases in TEC and the edges of spikes in electron densities at other locations. In the second case study (10 December 2015), phase scintillation was observed at a point associated with elevated TEC (Fig. 11e, f), but this was not associated with the assumed boundary of the polar hole.

When phase scintillation was observed, it was always associated with electron density gradients; however, the converse is not always true. Therefore, it appears that some minimum level of overall electron density is needed for phase scintillation to occur. Given that it is the presence of smallscale structures that cause scintillation, this suggests that these small-scale structures have not arisen.

Figure 12 shows phase scintillation as a function of TEC and the TEC rate of change. This figure also includes data from a third study (using data from 12 December 2015) that were consistent with the interpretation presented here but have been omitted in the interest of concision. Low scintillation can be seen at all TEC levels and for a majority of the range of TEC rates of change. Conversely, elevated scintillation levels are only seen above approximately 6 TECU, suggesting that a minimum electron density is required. This is not a new idea, in a review paper Aarons (1982) commented "if the ionosphere is perturbed on a percentage basis, change in $N$ in the trough will be small since $N$ is low; scintillations will then be low." The current paper provides observational evidence to support this suggestion that a minimum electron density is required. The current paper is also consistent with suggestions made by Prikryl et al. (2015), where the strongest phase scintillations were found to be highly colocated with regions that are ionospheric signatures of the coupling between the solar wind and magnetosphere. Polar 


\section{SuperDARN parameter plot Convection maps (1200_2358_1x1)}

(a)

15:42:00 - 15:44:00 UT

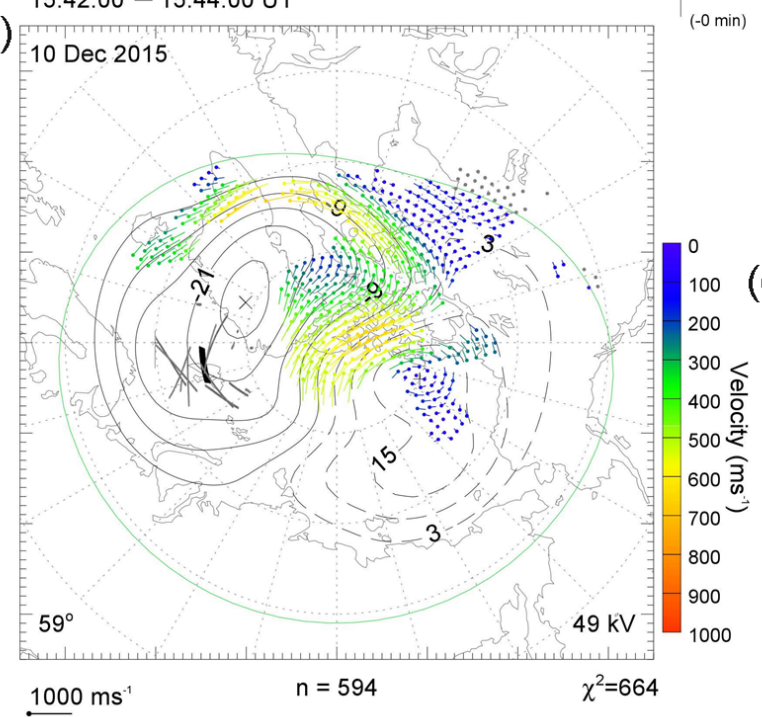

(b)

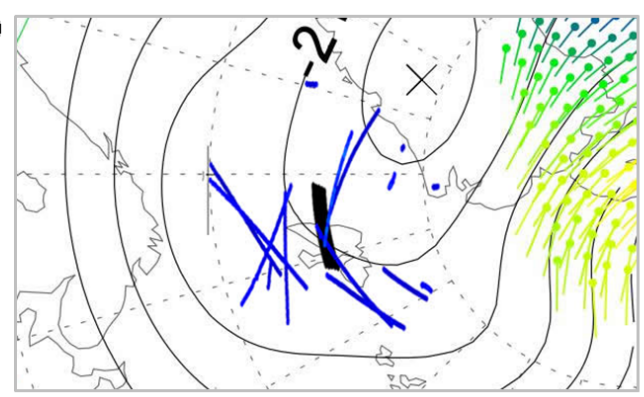

(c)

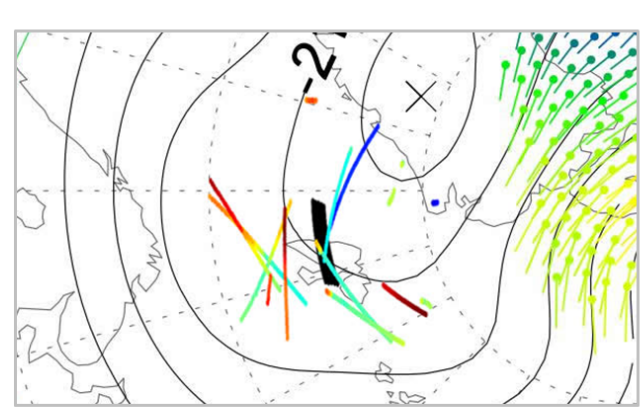

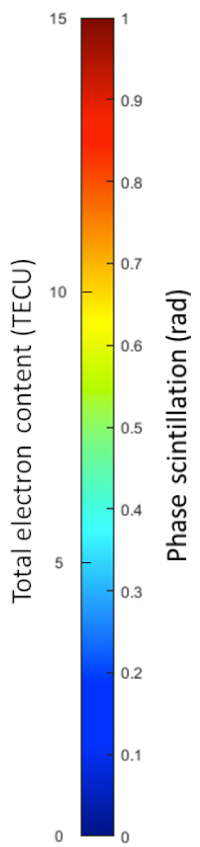

\section{SuperDARN parameter plot Convection maps (1200_2358_1x1)}

(d)

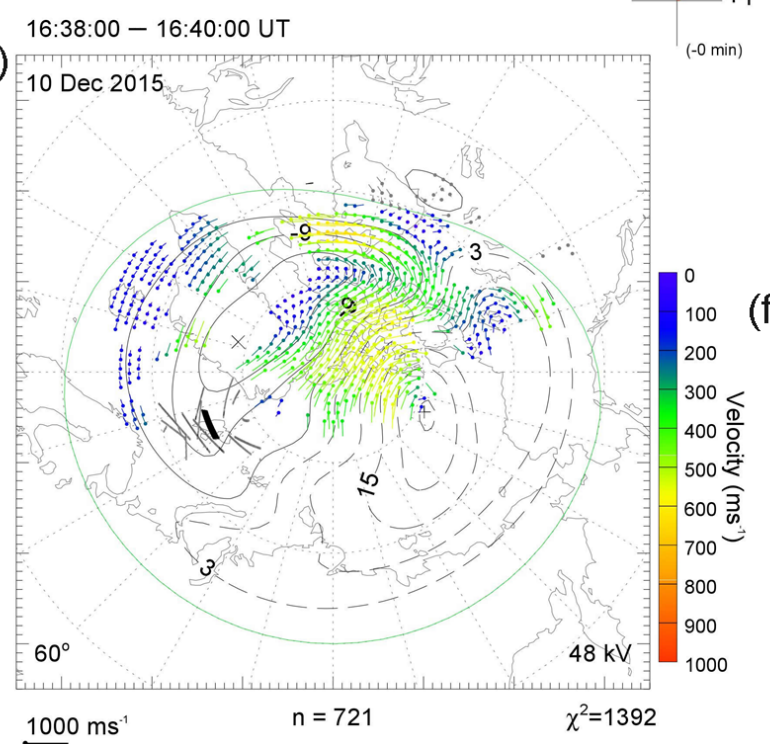

(e)

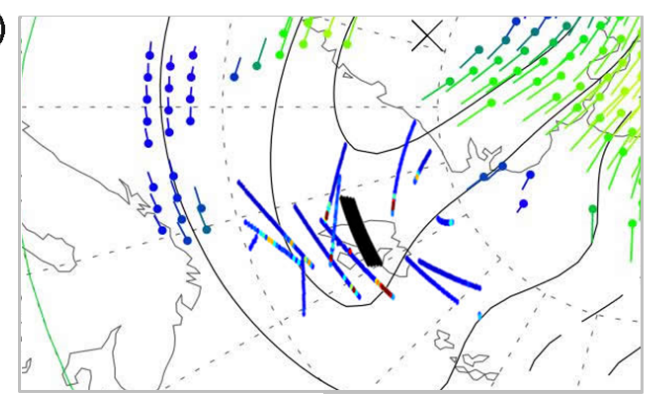

(f)

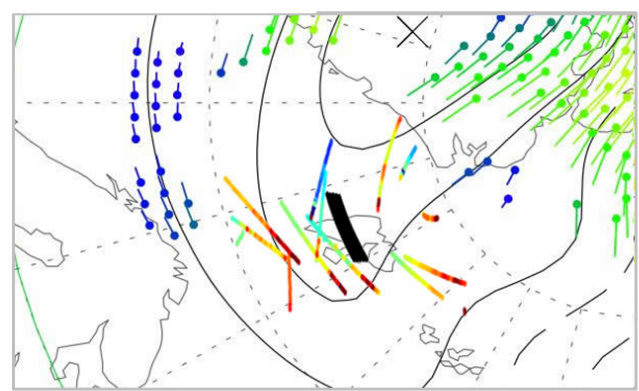

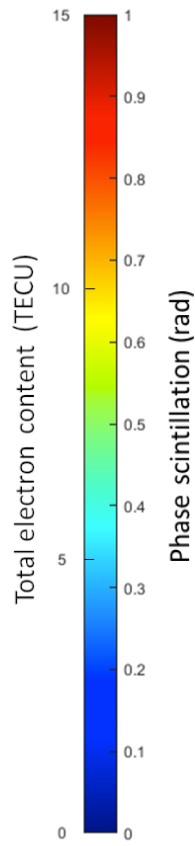

Figure 11. Electric potential patterns inferred from the SuperDARN radars for 15:42 and 16:38 UT on 10 December 2015, with data from GNSS satellites overlaid in the same format as in Fig. 5. The intervals for which the satellite passes were plotted are from 15:16 to 16:14 UT (15:42 UT plot) and from 16:14 to 17:04 UT (16:38 UT plot). 


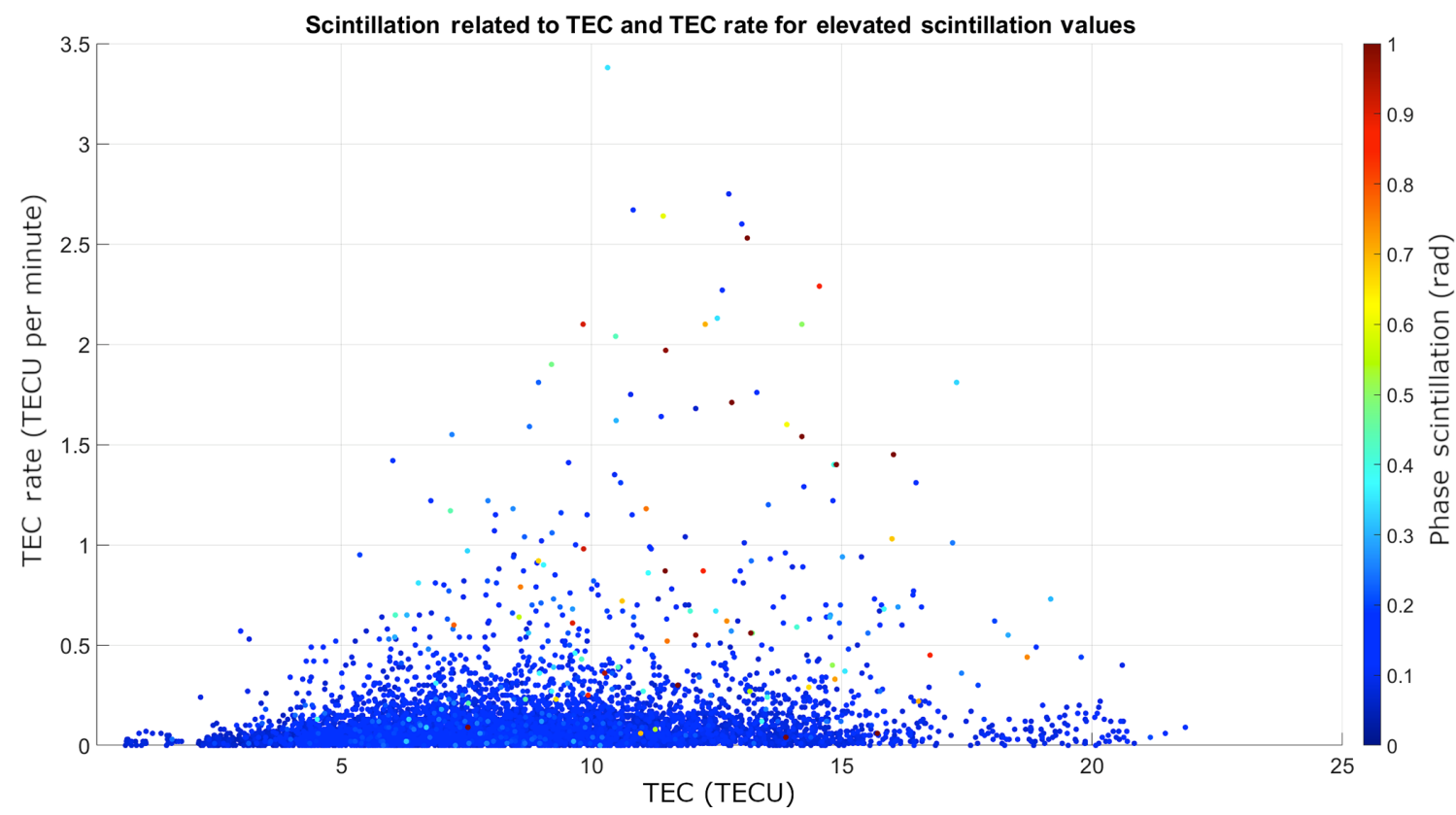

Figure 12. Phase scintillation as a function of TEC and the TEC rate of change per minute for 17 December 2014, 12 December 2015, and 10 December 2015.

holes appear to be areas of weak coupling, and, hence, less scintillation.

In this study, the phase scintillation index $\left(\sigma_{\phi}\right)$ has been calculated across a $60 \mathrm{~s}$ interval, which is in line with common practice within this field. However, if this index was computed across a shorter time interval, it is possible that elevated values of $\sigma_{\phi}$ may be associated with the edge of the polar hole. This would be an interesting topic for a future paper. Further developments upon this work would expand the observations of the polar holes discussed to a larger number of examples under a wider range of geophysical conditions. Polar ionospheric holes could be tracked by making observations with a higher temporal resolution at a large number of regularly spaced locations. The advent of EISCAT-3D (McCrea et al., 2015), which will give unprecedented temporal and spatial coverage, will enable such studies in the European sector of the high-latitude ionosphere. The ability to observe the evolution of polar holes over time will give a new, deeper understanding of these features and how they influence practical radio systems such as GNSS.

\section{Conclusions}

Polar ionospheric holes are regions of electron density depletions containing large electron density gradients at their boundaries. This paper reports case study observations of polar ionospheric holes conducted using the ESR and GNSS receivers. These holes were observed during both quiet and moderately disturbed geomagnetic conditions, under a range of solar activities. Steep electron density gradients have been associated with phase scintillation at GNSS frequencies in previous studies; however, no enhanced scintillation was detected upon the electron density gradients at these boundaries. Phase scintillation was only observed when electron density levels were elevated above 6 TECU. Aarons (1982) suggested that a minimum density level may be required for scintillation to occur, and the present study provides supporting observational evidence. We conclude that both a minimum electron density level and a sharp gradient in the election density must be present for instability mechanisms to produce scintillation structures.

Data availability. The data used in this paper are publicly available at https://www.eiscat.se (last access: 31 July 2019). SuperDARN data are available at https://vt.superdarn.org (last access: 31 July 2019). SuperDARN is a collection of radars funded by national scientific funding agencies of Australia, Canada, China, France, Italy, Japan, Norway, South Africa, the UK, and the USA. Data for TEC processing are provided from the following organisations: UNAVCO; Scripps Orbit and Permanent Array Center; Institut Geographique National, France; the International GNSS Service; the Crustal Dynamics Data Information System (CDDIS); the National Geodetic Survey; the Instituto Brasileiro de Geografia e Estatística, RAMSAC CORS of the Instituto Geográfico Nacional de la República Argentina; the Arecibo Observatory; the LowLatitude Ionospheric Sensor Network (LISN); Topcon Positioning Systems, Inc.; the Canadian High Arctic Ionospheric Network; the Centro di Ricerche Sismologiche; the Système d'Observation du Niveau des Eaux Littorales (SONEL); RENAG: REseau NAtional GPS permanent; GeoNet - the official source of geological hazard information for New Zealand; the GNSS Reference Networks; 
the Finnish Meteorological Institute; and SWEPOS - Sweden. Access to these data is provided by the Madrigal network: http://cedar. openmadrigal.org/ (last access: 31 July 2019). The Kp index and F10.7 cm solar flux were obtained from the UK Solar System Data Centre at Rutherford Appleton Laboratory. These can be accessed at https://www.ukssdc.ac.uk/ (last access: 31 July 2019). The IMF data were provided by Norman Ness and obtained from the CDAWeb at https://cdaweb.gsfc.nasa.gov/ (last access: 31 July 2019).

Author contributions. This work was led by LAJ, under the guidance of AGW. KO provided the GNSS TEC and scintillation data as well as guidance regarding their interpretation. TKY and ARF provided the SuperDARN electric potential maps as well as guidance regarding their interpretation. AJC provided the TEC maps and guidance regarding their interpretation. All authors contributed to the discussion. The paper was prepared by LAJ, GDD, and AGW.

Competing interests. The authors declare that they have no conflict of interest.

Acknowledgements. EISCAT is an international facility supported by the national science councils of China, Finland, Japan, Norway, Sweden, and the UK. Assistance from Ingemar Häggström and colleagues at the EISCAT Scientific Association with respect to running the experiments is gratefully acknowledged. Assistance from Steve Crothers and Matthew Wild at Rutherford Appleton Laboratory regarding the data processing is gratefully acknowledged. The GNSS TEC and scintillation data were provided by Kjellmar Oksavik at the University of Bergen, who both benefit from financial support from the Norwegian Research Council (grant nos. 212014 and 223252). Assistance from Nathan Brown with respect to the production of Figs. 5 and 11 is gratefully acknowledged. GPS TEC data products and access through the Madrigal distributed data system are provided to the community (http://www.openmadrigal.org, last access: 31 July 2019) by the Massachusetts Institute of Technology (MIT) with support from the US National Science Foundation (grant no. AGS-1242204).

Financial support. Luke A. Jenner was supported by internal funds from Nottingham Trent University. Alexandra R. Fogg was supported by a studentship from the Science and Technology Facilities Council (UK). Publication charges were met by Nottingham Trent University.

Review statement. This paper was edited by Keisuke Hosokawa and reviewed by two anonymous referees.

\section{References}

$\begin{array}{cccc}\text { Aarons, J.: Global } & \text { Morphology of } & \text { Ionospheric } \\ \text { Scintillations, } & \text { Proc. } & \text { IEEE, 70, 4, } & \text { 360-378, } \\ \text { https://doi.org/10.1109/PROC.1982.12314, 1982. } & \end{array}$

Alfonsi, L., Spogli, L., De Franceschi, G., Romano, V., Aquino, M., Dodson, A., and Mitchell, C. N.: Bipolar climatology of GPS ionospheric scintillation at solar minimum, Radio Sci., 46, RS0D05, https://doi.org/10.1029/2010RS004571, 2011.

Anderson, D. N., Buchau, J., and Heelis, R. A.: Origin of density enhancements in the winter polar cap ionosphere, Radio Sci., 23, 513-519, https://doi.org/10.1029/RS023i004p00513, 1988.

Benson, R. and Grebowsky, J.: Extremely low ionospheric peak altitudes In the polar hole region, Radio Sci., 36, 277-285, https://doi.org/10.1029/1999rs002401, 2001.

Briggs, B. H. and Parkin, I. A.: On the variation of radio star and satellite scintillation with zenith angle, J. Amos. Terr. Phys., 25, 339-365, https://doi.org/10.1016/0021-9169(63)90150-8, 1963.

Brinton, H., Grebowsky, J., and Brace, L.: The high-latitude winter F-region at $300 \mathrm{~km}$ : Thermal plasma observations from Ae-C, J. Geophys. Res., 83, 4767-4776, https://doi.org/10.1029/Ja083ia10p04767, 1978.

Buchau, J. and Reinisch, B. W.: Electron density structures in the polar F region, Adv. Space Res., 11, 29-37, https://doi.org/10.1016/0273-1177(91)90317-D, 1991.

Buchau, J., Reinisch, B. W., Weber, E. J., and Moore, J. G.: Structure and dynamics of the winter polar cap F region, Radio Sci., 18, 995-1010, https://doi.org/10.1029/RS018i006p00995, 1983.

Carlson, H. C., Oksavik, K., Moen, J., van Eyken, A. P., and Guio, P.: ESR mapping of polar-cap patches in the dark cusp, Geophys. Res. Lett., 29, 1386, https://doi.org/10.1029/2001GL014087, 2002.

Carlson, H. C., Oksavik, K., Moen, J., and Pedersen, T.: Ionospheric patch formation: Direct measurements of the origin of a polar cap patch, Geophys. Res. Lett., 31, L08806, https://doi.org/10.1029/2003GL018166, 2004.

Carlson, H. C., Moen, J., Oksavik, K., Nielsen, C. P., McCrea, I. W., Pedersen, T. R., and Gallop, P.: Direct observations of injection events of subauroral plasma into the polar cap, Geophys. Res. Lett., 33, L05103, https://doi.org/10.1029/2005GL025230, 2006.

Carlson, H. C., Oksavik, K., and Moen, J.: On a new process for cusp irregularity production, Ann. Geophys., 26, 2871-2885, https://doi.org/10.5194/angeo-26-2871-2008, 2008.

Cervera, M. A. and Thomas, R. M.: Latitudinal and temporal variation of equatorial ionospheric irregularities determined from GPS scintillation observations, Ann. Geophys., 24, 3329-3341, https://doi.org/10.5194/angeo-24-3329-2006, 2006.

Chisham, G., Lester, M., Milan, S. E., Freeman, M. P., Bristow, W. A., Grocott, A., McWilliams, K. A., Ruohoniemi, J. M., Yeoman, T. K., Dyson, P. L., Greenwald, R. A., Kikuchi, T., Pinnock, M., Rash, J. P. S., Sato, N., Sofko, G. J., Villain, J.P., and Walker, A. D. M.: A decade of the Super Dual Auroral Radar Network (SuperDARN): Scientific achievements, new techniques and future directions, Surv. Geophys., 28, 33-109, https://doi.org/10.1007/s10712-007-9017-8, 2007.

Cowley, S. W. H. and Lockwood, M.: Excitation and decay of solar-wind driven flows in the magnetosphere-ionosphere system, Ann. Geophys., 10, 103-115, 1992.

Crowley, G.: Critical Review of patches and blobs, in Polar Cap Boundary Phenomena, in: URSI Review of Radio Science 19931996, edited by: Stone, W. R., published for the International Union of Radio Science, Oxford University Press, 619-648, https://doi.org/10.1029/2009JA014985, 1996. 
De Franceschi, G., Spogli, L., Alfonsi, L., Romano, V., Cesaroni, C., and Hunstad, I.: The ionospheric irregularities climatology over Svalbard from solar cycle 23, Sci. Rep.-UK, 9, 9232, https://doi.org/10.1038/s41598-019-44829-5, 2019.

Elmas, Z., Forte, B., and Aquino, A.: The impact of ionospheric scintillation on the GNSS receiver signal tracking performance and measurement accuracy, URSI General Assembly and Scientific Symposium, https://doi.org/10.1109/URSIGASS.2011.6123719, 2011.

Forte, B.: Optimum detrending of raw GPS data for scintillation measurements at auroral latitudes, J. Atmos. Sol.-Terr. Phy., 67, 1100-1109, https://doi.org/10.1016/j.jastp.2005.01.011, 2005.

Forte, B. and Radicella, S.: Problems in data treatment for ionospheric scintillation measurements, Radio Sci., 37, 81-85, https://doi.org/10.1029/2001rs002508, 2002.

Foster, J. C.: Ionospheric signatures of magnetospheric convection, J. Geophys. Res., 89, 855-865, https://doi.org/10.1029/JA089iA02p00855, 1984.

Fremouw, E. J., Leadabrand, R. L., Livingston, R. C., Cousins, M. D., Rino, C. L., Fair, B. C., and Long, R. A.: Early results from the DNA wideband satellite experiment - Complex-signal scintillation, Radio Sci., 13, 167-187, https://doi.org/10.1029/RS013i001p00167, 1978.

Greenwald, R. A., Baker, K. B., Dudeney, J. R., Pinnock, M., Jones, T. B., Thomas, E. C., Vilain, J. P., Cerisier, J. C., Senior, C., Hanuise, C., Hunsucker, R. D., Sofko, G., Koehler, J., Neilsen, E., Pellinen, R., Walker, A. D. M., Sato, N., and Yamagishi, H.: DARN/SuperDARN: A global view of high latitude convection, Space Sci. Rev., 71, 761-796, https://doi.org/10.1007/BF00751350, 1995.

Hapgood, M.: Satellite navigation - Amazing technology but insidious risk: Why everyone needs to understand space weather, Space Weather, 15, 545-548, https://doi.org/10.1002/2017SW001638, 2017.

Jin, Y., Moen, J. I., Miloch, W. J., Clausen, L. B. N., and Oksavik, K.: Statistical study of the GNSS phase scintillation associated with two types of auroral blobs, J. Geophys. Res.-Space, 121, 4679-4697, https://doi.org/10.1002/2016JA022613, 2016.

Jin, Y., Moen, J., Oksavik, K., Spicher, A., Clausen, L., and Miloch, W.: GPS scintillations associated with cusp dynamics and polar cap patches, J. Space Weather Space Clim., 7, A23 https://doi.org/10.1051/swsc/2014019, 2017.

Jones, D. G., Walker, I. K., and Kersley, L.: Structure of the poleward wall of the trough and the inclination of the geomagnetic field above the EISCAT radar, Ann. Geophys., 15, 740-746, https://doi.org/10.1007/s00585-997-0740-8, 1997.

Kersley, L., Jenkins, D., and Edwards, K.:, Relative Movements of Mid-Latitude Trough and Scintillation Boundary. Nature Phys. Sci., 239, 11, https://doi.org/10.1038/physci239011a0, 1972.

Kersley, L., Russell, C. D., and Rice, D. L.: Phase scintillation and irregularities in the northern polar ionosphere, Radio Sci., 30, 619, https://doi.org/10.1029/94RS03175, 1995.

Keskinen, M. J. and Ossakow, S. L.: Theories of high-latitude ionospheric irregularities: A review, Radio Sci., 18, 1077-1091, https://doi.org/10.1029/RS018i006p01077, 1983.

Kinrade, J., Mitchell, C. N., Smith, N. D., Ebihara, Y., Weatherwax, A. T., and Bust, G. S.: GPS phase scintillation associated with optical auroral emissions: First statistical results from the geo- graphic South Pole, J. Geophys. Res.-Space, 118, 2490-2502, https://doi.org/10.1002/jgra.50214, 2013.

Lockwood, M. and Carlson, H. C.: Production of polar cap electron density patches by transient magnetopause reconnection, Geophys. Res. Lett., 19, 1731-1734, 1992.

McCaffrey, A. M. and Jayachandran, P. T.: Determination of the refractive contribution to GPS phase "scintillation”, J. Geophys. Res.-Space, 124, 1454-1469, https://doi.org/10.1029/2018JA025759, 2019.

McCrea, I., Aikio, A., Alfonsi, L., Belova, E., Buchert, S., Clilverd, M., Engler, N., Gustavsson, B., Heinselman, C., Kero, J., Kosch, M., Lamy, H., Leyser, T., Ogawa, Y., Oksavik, K., PellinenWannberg, A., Pitout, F., Rapp, M., Stanislawska, I., and Vierinen, J.: The science case for the EISCAT_3D radar, Prog. Earth Planet. Sci., 2, 21, https://doi.org/10.1186/s40645-015-0051-8, 2015.

Millward, G. H., Moffett, R. J., Balmforth, H. F., and Rodger, A. S.: Modeling the ionospheric effects of ion and electron precipitation in the cusp, J. Geophys. Res., 104, 24603, https://doi.org/10.1029/1999JA900249, 1999.

Mitchell, C. N., Alfonsi, L., De Franceschi, G., Lester, M., Romano, V., and Wernik, A. W.: GPS TEC and scintillation measurements from the polar ionosphere during the October 2003 storm, Geophys. Res. Lett., 32, L12S03, https://doi.org/10.1029/2004GL021644, 2005.

Nishimura, Y., Lyons, L. R., Zou, Y., Oksavik, K., Moen, J. I., Clausen, L. B., Donovan, E. F., Angelopoulos, V., Shiokawa, K., Ruohoniemi, J. M., Nishitani, N., McWilliams, K. A., and Lester, M.: Day-night coupling by a localized flow channel visualized by polar cap patch propagation, Geophys. Res. Lett., 41, 37013709, https://doi.org/10.1002/2014GL060301, 2014.

Nishitani, N., Ruohoniemi, J. M., Lester, M., Baker, J. B. H., Koustov, A. V., Shepherd, S. G., Chisham, G., Hori, T., Thomas, E. G., Makarevich, R. A., Marchaudon, A., Ponomarenko, P., Wild, J. A., Milan, S. E., Bristow, W. A., Devlin, J., Miller, E., Greenwald, R. A., Ogawa, T., and Kikuchi, T.: Review of the accomplishments of mid-latitude Super Dual Auroral Radar Network (SuperDARN) HF radars, Prog. Earth Planet. Sci., 6, 27, https://doi.org/10.1186/s40645-019-0270-5, 2019.

Obara, T. and Oya, H.: Observations of polar cusp and polar cap ionospheric irregularities and formation of ionospheric holes using topside sounder onboard Exos-C (Ohzora) satellite, J. Geomagn. Geoelectr., 41, 1025-1042, https://doi.org/10.5636/Jgg.41.1025, 1989.

Oksavik, K., Barth, V. L., Moen, J., and Lester, M.: On the entry and transit of high-density plasma across the polar cap, J. Geophys. Res., 115, A12308, https://doi.org/10.1029/2010JA015817, 2010.

Oksavik, K., van der Meeren, C., Lorentzen, D. A., Baddeley, L. J., and Moen, J.: Scintillation and loss of lock from poleward moving auroral forms in the cusp ionosphere, J. Geophys. Res.Space, 120, 9161-9175, https://doi.org/10.1002/2015JA021528, 2015.

Parkinson, M. L., Dyson, P. L., Pinnock, M., Devlin, J. C., Hairston, M. R., Yizengaw, E., and Wilkinson, P. J.: Signatures of the midnight open-closed magnetic field line boundary during balanced dayside and nightside reconnection, Ann. Geophys., 20, 16171630, https://doi.org/10.5194/angeo-20-1617-2002, 2002. 
Prikryl, P., Jayachandran, P. T., Chadwick, R., and Kelly, T. D.: Climatology of GPS phase scintillation at northern high latitudes for the period from 2008 to 2013, Ann. Geophys., 33, 531-545, https://doi.org/10.5194/angeo-33-531-2015, 2015.

Pryse, S. E., Kersley, L., and Russell, C. D.: Scintillation near the F layer trough over northern Europe, Radio Sci., 26, 1105-1114, https://doi.org/10.1029/91RS00490, 1991.

Pryse, S. E., Wood, A. G., Middleton, H. R., McCrea, I. W., and Lester, M.: Reconfiguration of polar-cap plasma in the magnetic midnight sector, Ann. Geophys., 24, 2201-2208, https://doi.org/10.5194/angeo-24-2201-2006, 2006.

Rideout, W. and Coster, A. J.: Automated GPS processing for global total electron content data, GPS Solut., 10, 219-228, https://doi.org/10.1007/s10291-006-0029-5, 2006.

Rino, C. L., Livingston, R. C., Tsunoda, R. T., Robinson, R. M., Vickrey, J. F., Senior, C., Cousins, M. D., Owen, J., and Klobuchar, J. A.: Recent studies of the structure and morphology of auroral-zone F-region irregularities, Radio Sci., 18, 11671180, https://doi.org/10.1029/RS018i006p01167, 1983.

Rodger, A. S., Pinnock, M., Dudeney, J. R., Baker, K. B., and Greenwald, R. A.: A new mechanism for polar patch formation, J. Geophys. Res., 99, 6425-6436, https://doi.org/10.1029/93JA01501, 1994.

Ruohoniemi, J. M. and Baker, K. B.: Large-scale imaging of highlatitude convection with Super Dual Auroral Radar Network HF radar observations, J. Geophys. Res., 103, 20797-20811, 1998.

Smith, A. M., Mitchell, C. N., Watson, R. J., Meggs, R. W., Kintner, P. M., Kauristie, K., and Honary, F.: GPS scintillation in the high arctic associated with an auroral arc, Space Weather, 6, S03D01, https://doi.org/10.1029/2007SW000349, 2008.

Sojka, J., Bowline, M., Schunk, R., Decker, D., Valladares, C., Sheehan, R., Anderson, D., and Heelis, R.: Modeling Polar Cap F-Region Patches Using Time Varying Convection, Geophys. Res. Lett., 20, 1783-1786, https://doi.org/10.1029/93g101347, 1993.

Spogli, L., Alfonsi, L., De Franceschi, G., Romano, V., Aquino, M. H. O., and Dodson, A.: Climatology of GPS ionospheric scintillations over high and mid-latitude European regions, Ann. Geophys., 27, 3429-3437, https://doi.org/10.5194/angeo-27-34292009, 2009.

Thomas, E. G. and Shepherd, S. G.: Statistical patterns of ionospheric convection derived from mid-latitude, high-latitude, and polar SuperDARN HF radar observations, J. Geophys. Res., 123, 3196-3216, https://doi.org/10.1002/2018JA025280, 2018.

Tsunoda, R. T.: High-latitude $F$ region irregularities: A review and synthesis, Rev. Geophys., 26, 719-760, https://doi.org/10.1029/RG026i004p00719, 1988.

Valladares, C. E., Basu, S., Buchau, J., and Friis-Christensen, E.: Experimental evidence for the formation and entry of patches into the polar cap, Radio Sci., 29, 167-194, https://doi.org/10.1029/93RS01579, 1994.
Valladares, C. E., Decker, D. T., Sheehan, R., Anderson, D. N., Bullett, T., and Reinisch, B. W.: Formation of polar cap patches associated with north-to-south transitions of the interplanetary magnetic field, J. Geophys. Res., 103, 14657-14670, https://doi.org/10.1029/97JA03682, 1998.

van der Meeren, C., Oksavik, K., Lorentzen, D., Moen, J. I., and Romano, V.: GPS scintillation and irregularities at the front ofan ionization tongue in the night-side polar ionosphere, J. Geophys. Res.-Space, 119, 8624-8636, https://doi.org/10.1002/2014JA020114, 2014.

van der Meeren, C., Oksavik, K., Lorentzen, D. A., Rietveld, M. T., and Clausen, L. B. N.:, Severe and localized GNSS scintillation at the poleward edge of the nightside auroral oval during intense substorm aurora, J. Geophys. Res.-Space, 120, 1060710621, https://doi.org/10.1002/2015JA021819, 2015.

van der Meeren, C., Oksavik, K., Lorentzen, D. A., Paxton, L. J., and Clausen, L. B. N.: Scintillation and irregularities from the nightside part of a Sun-aligned polar cap arc, J. Geophys. Res.Space, 121, 5723-5736, https://doi.org/10.1002/2016JA022708, 2016.

Vierinen, J., Coster, A. J., Rideout, W. C., Erickson, P. J., and Norberg, J.: Statistical framework for estimating GNSS bias, Atmos. Meas. Tech., 9, 1303-1312, https://doi.org/10.5194/amt-9-13032016, 2016.

Walker, I. K., Moen, J., Kersley, L., and Lorentzen, D. A.: On the possible role of cusp/cleft precipitation in the formation of polar-cap patches, Ann. Geophys., 17, 1298-1305, https://doi.org/10.1007/s00585-999-1298-4, 1999.

Wang, Y., Zhang, Q.-H., Jayachandran, P. T., Moen, J., Xing, Z.Y., Chadwick, R., Ma, Y.-Z., Ruohoniemi, J. M., and Lester, M.: Experimental evidence on the dependence of the standard GPS phase scintillation index on the ionospheric plasma drift around noon sector of the polar ionosphere, J. Geophys. Res.-Space, 123 , 2370-2378, https://doi.org/10.1002/2017JA024805, 2018.

Wannberg, G., Wolf, I., Vanhainen, L.-G., Koskenniemi, K., Röttger, J., Postila, M., Markkanen, J. Jacobsen, R., Stenberg, A., Larsen, R., Eliassen, S., Heck, S., and Huuskonen, A.: The EISCAT Svalbard radar: A case study in modern incoherent scatter radar system design, Radio Sci., 32, 2283-2308, https://doi.org/10.1029/97RS01803, 1997.

Weber, E., Buchau, J., Moore, J., Sharber, J., Livingston, R., Winningham, J., and Reinisch, B.: F-layer ionization patches in the polar cap, J. Geophys. Res., 89, 1683, https://doi.org/10.1029/Ja089ia03p01683, 1984.

Weber, E. J., Klobuchar, J. A., Buchau, J., Carlson Jr., H. C., Livingston, R. C., de la Beaujadiere, O., McCready, M., Moore, J. G., and Bishop, G. J.: Polar cap F layer patches: Structure and dynamics, J. Geophys. Res., 91, 12121-12129, 1986.

Zwickl, R. D., Doggett, K. A., Sahm, S., Barrett, W. P., Grubb, R. N., Detman, T. R., Raben, V. J., Smith, C. W., Riley, P., Gold, R. E., Mewaldt, R. A., and Maruyama, T.: The NOAA Real-Time Solar-Wind (RTSW) system using ACE data, Space Sci. Rev., 86, 633-648, https://doi.org/10.1023/A:1005044300738, 1998. 